\title{
Biomaterial-Supported Cell Transplantation Treatments for Spinal Cord Injury: Challenges and Perspectives
}

\author{
Shengwen Liu ${ }^{1,2}$, Thomas Schackel ${ }^{1}$, Norbert Weidner ${ }^{1}$ and Radhika Puttagunta ${ }^{\text {1* }}$ \\ ' Spinal Cord Injury Center, Heidelberg University Hospital, Heidelberg, Germany, ${ }^{2}$ Department of Neurosurgery, Tongji \\ Hospital, Tongji Medical College, Huazhong University of Science and Technology, Wuhan, China
}

Spinal cord injury $(\mathrm{SCl})$, resulting in para- and tetraplegia caused by the partial or complete disruption of descending motor and ascending sensory neurons, represents a complex neurological condition that remains incurable. Following $\mathrm{SCl}$, numerous obstacles comprising of the loss of neural tissue (neurons, astrocytes, and oligodendrocytes), formation of a cavity, inflammation, loss of neuronal circuitry and function must be overcome. Given the multifaceted primary and secondary injury events that occur with SCI treatment options are likely to require combinatorial therapies. While several methods have been explored, only the intersection of two, cell transplantation and biomaterial implantation, will be addressed in detail here. Owing to the constant advance

OPEN ACCESS

Edited by:

Vann Bennett,

Howard Hughes Medical Institute (HHMI), United States

Reviewed by:

Gregory W. J. Hawryluk, University of Utah, United States

Florence Evelyne Perrin Université de Montpellier, France

${ }^{*}$ Correspondence: Radhika Puttagunta radhika.puttagunta@ med.uni-heidelberg.de

Received: 21 August 2017 Accepted: 20 December 2017 Published: 11 January 2018

Citation:

Liu S, Schackel T, Weidner N and Puttagunta R (2018)

Biomaterial-Supported Cell Transplantation Treatments for Spinal

Cord Injury: Challenges and

Perspectives.

Front. Cell. Neurosci. 11:430. doi: 10.3389/fncel.2017.00430 of cell culture technologies, cell-based transplantation has come to the forefront of SCl treatment in order to replace/protect damaged tissue and provide physical as well as trophic support for axonal regrowth. Biomaterial scaffolds provide cells with a protected environment from the surrounding lesion, in addition to bridging extensive damage and providing physical and directional support for axonal regrowth. Moreover, in this combinatorial approach cell transplantation improves scaffold integration and therefore regenerative growth potential. Here, we review the advances in combinatorial therapies of Schwann cells (SCs), astrocytes, olfactory ensheathing cells (OECs), mesenchymal stem cells, as well as neural stem and progenitor cells (NSPCs) with various biomaterial scaffolds.

Keywords: cell transplantation, biomaterial scaffolds, spinal cord injury, axonal regeneration, combinatorial therapy

\section{INTRODUCTION}

Traumatic spinal cord injury (SCI) results in the disruption of neuronal circuitry leading to the partial or complete loss of motor control, autonomic function and sensory input. Paraplegic or tetraplegic patients must also contend with chronic consequences ranging from spasticity, neuropathic pain, bladder and bowel dysfunction, pressure ulcers, respiratory and cardiovascular complications which significantly decreases quality of life. World-wide SCI has an annual incidence ranging from 20 to 30 patients per million people (Lee et al., 2014; Singh et al., 2014; Jain et al., 2015; Jazayeri et al., 2015). However, to date there is no effective SCI therapy that can entirely restore neurological deficits. Such therapies must address various complex obstacles that develop 
after SCI, in particular, cyst formation, neural cell death, a growth-inhibitory microenvironment, scar formation, demyelination, and the disruption of the blood supply (Silva et al., 2014). Although, any treatment option that allows a patient to partially regain lost neuronal circuitry, whether it be motor, sensory or autonomic, will prove to be invaluably beneficial.

In previous decades, a myriad of experimental studies have been conducted to develop potential treatment options for SCI patients. Many studies showed a certain degree of morphological changes partially accompanied by behavioral improvements in various animal models (Fouad et al., 2005; Blesch and Tuszynski, 2009; Franz et al., 2012; McCall et al., 2012; Zhao et al., 2013; Danilov and Steward, 2015; Gomes-Osman et al., 2016; Kadoya et al., 2016). Amongst these studies, cell-based transplantation has been considered as a promising therapeutic strategy due to: (1) direct replacement of the damaged neural tissue, (2) neuroprotective properties for spared neuronal connections, and (3) providing a permissive and supportive cellular growth substrate for axonal regrowth and/or plasticity (Ohta et al., 2004; Feron et al., 2005; Granger et al., 2014; Kanno et al., 2015). Obstacles for cell-based transplantation therapy remain to be the low survival rates of the grafted cells after transplantation into the injured spinal cord, retention of grafted cell at the lesion site without migration, filling the lesion cavity that has formed as well as directional guidance of axonal growth (Pearse and Barakat, 2006; Pearse et al., 2007; Parr et al., 2008; Takahashi et al., 2011). Although a huge effort has been made to modify delivery mechanisms and surgical techniques, success has been modest and relatively inconsistent. In addition to the beneficial effects stated above, some drawbacks of cell transplantation must also be stated and further explored, including tumorgenic formation (Matsuda et al., 2009; Fu et al., 2012; Liu et al., 2013), maladaptive plasticity such as pain hypersensibility (Hofstetter et al., 2005; Macias et al., 2006; Davies et al., 2008), non-beneficial differentiation or dedifferentiation (Hill et al., 2004; Lepore et al., 2004), increased immunoreactivity to transplanted cells (Swanger et al., 2005), complications arising from surgical delivery (Takahashi et al., 2011) and deficits due to immunosuppression (Antonic et al., 2013). Nonetheless, some candidate cell types have already been investigated in clinical trials in SCI patients such as autologous (cells from the same individual) Schwann cells (SCs) (Anderson et al., 2017), olfactory ensheathing cells (OECs) (Mackay-Sim et al., 2008; Tabakow et al., 2013), bone-marrow mesenchymal stem cells (BMSCs) (Park et al., 2005; Kumar et al., 2009; Karamouzian et al., 2012; Mendonca et al., 2014; Oraee-Yazdani et al., 2016) and different neural stem and progenitor cells (NSPCs) (Shin et al., 2015).

Biomaterials have been combined with various cell types to address the issues of cell viability, cell retention at the lesion site, supportive physical matrix, filling of the lesion cavity as well as mediating directed growth (Atala, 2000; Madigan et al., 2009; Cao et al., 2011; Luo et al., 2016; Ogle et al., 2016). Numerous studies have proven diverse biomaterials to be appropriate delivery vehicles for cells as well as bioactive molecules and drugs in different injury and disease models in the central nervous system (CNS) (Krishna et al., 2013; Führmann et al., 2017).

\section{FUNCTION OF CELL-SEEDED BIOMATERIALS IN EXPERIMENTAL SCI MODELS}

Biomaterial scaffolds can fulfill multiple functions for SCI transplantation approaches: (1) specific three-dimensional microarchitectures can be designed with small "chambers" or aligned channels/fibers suited for cell seeding and axonal growth in a directed linear pattern facilitating substantial axonal growth across the lesion for establishment of synaptic connections (Gros et al., 2010; Gunther et al., 2015a; Onuma-Ukegawa et al., 2015); (2) serves as a physical matrix for cell adhesion and thereby enhancing survival and retention of grafted cells at the lesion site (Hurtado et al., 2006; Olson et al., 2009; Bozkurt et al., 2010; Park et al., 2012) and affect host cell migration (e.g., SCs and astrocytes) (Suzuki et al., 2015); (3) influence the behavior of grafted cells and differentiation (Mekhail et al., 2015); and (4) control the release of encapsulated bio-active molecules (Mothe et al., 2013).

Biomaterials can be fabricated from natural or synthetic polymers and subdivided into three major forms: solid scaffolds, hydrogels and micro-/nanoparticles (Boisserand et al., 2016). Various types of biomaterials have been explored in tissue engineering for SCI repair (Table 1). Crosslinking of hydrogels typically increases the overall long-term stability of biomaterials, however this also increases the stiffness and the balance between stiffness and stability is a delicate one for cell adhesion, migration and neuroregenerative work (Khaing et al., 2011; Seyedhassantehrani et al., 2016). Additionally, surface modification with extracellular matrix (ECM) components, e.g., laminin and fibronectin, or synthetic peptides represents another way to improve cell adhesion and survival by generating a less hostile molecular microenvironment within the biomaterial (Miller et al., 2001; Chen et al., 2009). Injectable in situ polymerizing hydrogels help to deliver cells and factors directly into a lesion site with less invasive surgical interventions, forming a homogenous three-dimensional matrix mimicking natural ECM microstructure to modulate cell fate (Bidarra et al., 2014; Führmann et al., 2016). Importantly, biomaterials can effectively fill a cystic cavity and bridge the lesion dramatically reducing the number of cells required for transplantation. This is particularly appealing for clinical use since the availability of autologous cells from patients is limited.

The potential of biomaterial application alone in SCI treatment has been explored in numerous pre-clinical studies and now even clinical trials (Carballo-Molina and Velasco, 2015; Siebert et al., 2015; Theodore et al., 2016; Xiao et al., 2016). Fibroglial scarring around the graft is a prominent phenomenom after biomaterial scaffold implantation. Typically, only sparse axons re-enter the caudal host spinal cord, while most are confined within the scar surrounding the implants (Suzuki et al., 2002; Grulova et al., 2015; Gunther et al., 2015b; Pawar et al., 2015a; Figure 1). To overcome this barrier without interference with its beneficial roles, targeting inhibitory molecules is one possible solution. For instance, delivery of Chondroitin sulfate proteoglycan (CSPG) cleaving enzyme chondroitinase $\mathrm{ABC}$ 
TABLE 1 | Biomaterials of different origins used for animal SCl experimentation.

\begin{tabular}{ll}
\hline Origin & Biomaterials \\
\hline Natural & Agarose \\
Alginate & Chitosan \\
Collagen & Fibrin \\
Fibronectin \\
Gellan gum \\
Hyaluronan \\
Hyaluronic acid \\
Calcium sulfate cement \\
Oligo[poly(ethylene glycol) fumarate] (OPF) \\
Poly(ethylene glycol) (PEG) \\
Poly-b-hydroxybutyrate (PHB) \\
Poly(2-hydroxyethylmethacrylate) (PHEMA) \\
Poly(D, L-lactic acid) (PLA) \\
Poly(lactide-co-glycolide) (PLG) \\
Poly(lactic-co-glycolic acid) (PLGA)
\end{tabular}

(ChABC) rostral and caudal to the graft was able to facilitate axonal growth through and beyond the scar (Fouad et al., 2005). Alternatively, cell injections into the host parenchyma around the biomaterial implantation site provide a continous permissive cellular substrate spanning the lesion cavity and biomaterial bridge (tissue bridging) (Ramon-Cueto et al., 1998; Fouad et al., 2005; Deumens et al., 2006a; Liu et al., 2017).

In this review, we assess combinatorial strategies of biomaterial-supported cell transplantation to reconstruct lost host tissue physically, cellularly and chemically after SCI. This includes the integration of biomaterials into the host tissue, bridging the host-graft interface, limiting the effect of the surrounding scar formation which may prevent axonal growth into and through the injury site as well as increasing cell survival to provide the axons with physical, directional guidance and trophic support to regenerate toward disconnected targets (Geller and Fawcett, 2002; Tetzlaff et al., 2011; Kim et al., 2014; Assuncao-Silva et al., 2015; Wu et al., 2015; Lin et al., 2016). Candidate cell populations that enhance biomaterial integration into host tissue such as SCs, astrocytes, OECs, mesenchymal stem cells as well as NSPCs (Tetzlaff et al., 2011; Wu et al., 2015; Badner et al., 2017) will be discussed here.

The delivery method of biomaterials and cells into a SCI has been undertaken by several different techniques which we will group into categories here for reference throughout the review (Figure 2). Category I, transplantation matrix, is when cells and biomaterials are mixed together in vitro and allowed to form a matrix prior to implantation. This technique has been widely used as a delivery system to confine the transplanted cells to the injury site and will not be covered extensively in this review. Category II, pre-seeded scaffold, is when a prefabricated biomaterial is seeded with cells prior to implantation. This technique is primarily used for solid scaffolds with a pre-determined shape. Category III, injection and in situ gelling, is when self-assembling biomaterials are injected along with cells into the injury site to assemble a seeded scaffold in vivo. This technique has become popular to fill irregular lesion cavities that form after SCI. Category IV, facilitated biomaterial implantation, is when a biomaterial is implanted and cells are injected surrounding the biomaterial. This technique has been used to increase the integration of the scaffold into the host tissue, to increase axonal bridging.

\section{CELLULAR CANDIDATES Schwann Cells}

In the peripheral nervous system, SCs are vital for regenerative growth following an axonal injury by providing trophic and physical support as well as remyelination (Rath et al., 1995; Triolo et al., 2006). SCs secrete ECM components (Tabesh et al., 2009) and neurotrophic factors such as brain-derived neurotrophic factor (BDNF), neurotrophin-3 (NT-3), nerve growth factor (NGF) (Dey et al., 2013; Godinho et al., 2013) and glial cellderived neurotrophic factor (GDNF) (Iannotti et al., 2004). Therefore, transplantation of SCs after SCI has been widely studied and numerous results demonstrate that SCs can support survival and maintenance of spared neural tissue, bridge lesion cavities, promote re-growth of both motor and sensory axons into the lesion after engraftment and remyelinate CNS axons (Xu et al., 1997; Weidner et al., 1999; Marcol et al., 2015). Unfortunately, SCs form a distinct divide between themselves and CNS tissue both in vitro and in vivo (Ghirnikar and Eng, 1994; Lakatos et al., 2000). A reformation of the glial limitans and increased production of growth inhibitory CSPG (Plant et al., 2001) likely restrict the regenerative effect of SCs on descending motor neuronal tracts (Vroemen et al., 2007; Kanno et al., 2014).

$\mathrm{Xu}$ and colleagues conducted a series of studies demonstrating that naïve SCs or SCs overexpressing neurotropic factors embedded in a semi-permeable single channel composed of polyacrylonitrile and polyvinylchloride copolymers (PAN/PVC) (Category II) in T8 hemisection and transection rat SCI models enhanced the growth of propriospinal and some supraspinal axons into the lesion (Xu et al., 1995a,b, 1997, 1999). However, most often axons did not exit the lesion site on the caudal side likely due to the formation of the glial limitans restricting the SC migration and further beneficial effects. In addition, in a rat C4 2-3 mm hemisection model, biodegradable tubular poly- $\beta$ hydroxybutyrate (PHB) scaffolds filled with SCs (Category II) were able to support the survival of the SCs by promoting attachment as well as facilitating raphespinal and sensory axonal growth within the conduit; similar to previous observations, no rubrospinal or corticospinal tract (CST) re-growth was observed (Novikova et al., 2008).

To address the lack of re-innervation of the uninjured host parenchyma caudal to the biomaterial bridge by regenerating axons one aspect is to limit the formation of the glial limitans and reactive astrogliosis. One method that at least extended growth of descending axons (serotonergic) back out of a $2 \mathrm{~mm}$ alginate-based anisotropic capillary hydrogel in a C4 unilateral hemisection was the injection of SCs caudal to the SC-seeded hydrogel with the additional caudal viral expression of BDNF (Liu et al., 2017) (Category II and IV). Further work needs to be done to elucidate if this moved the glial limitans further down the 


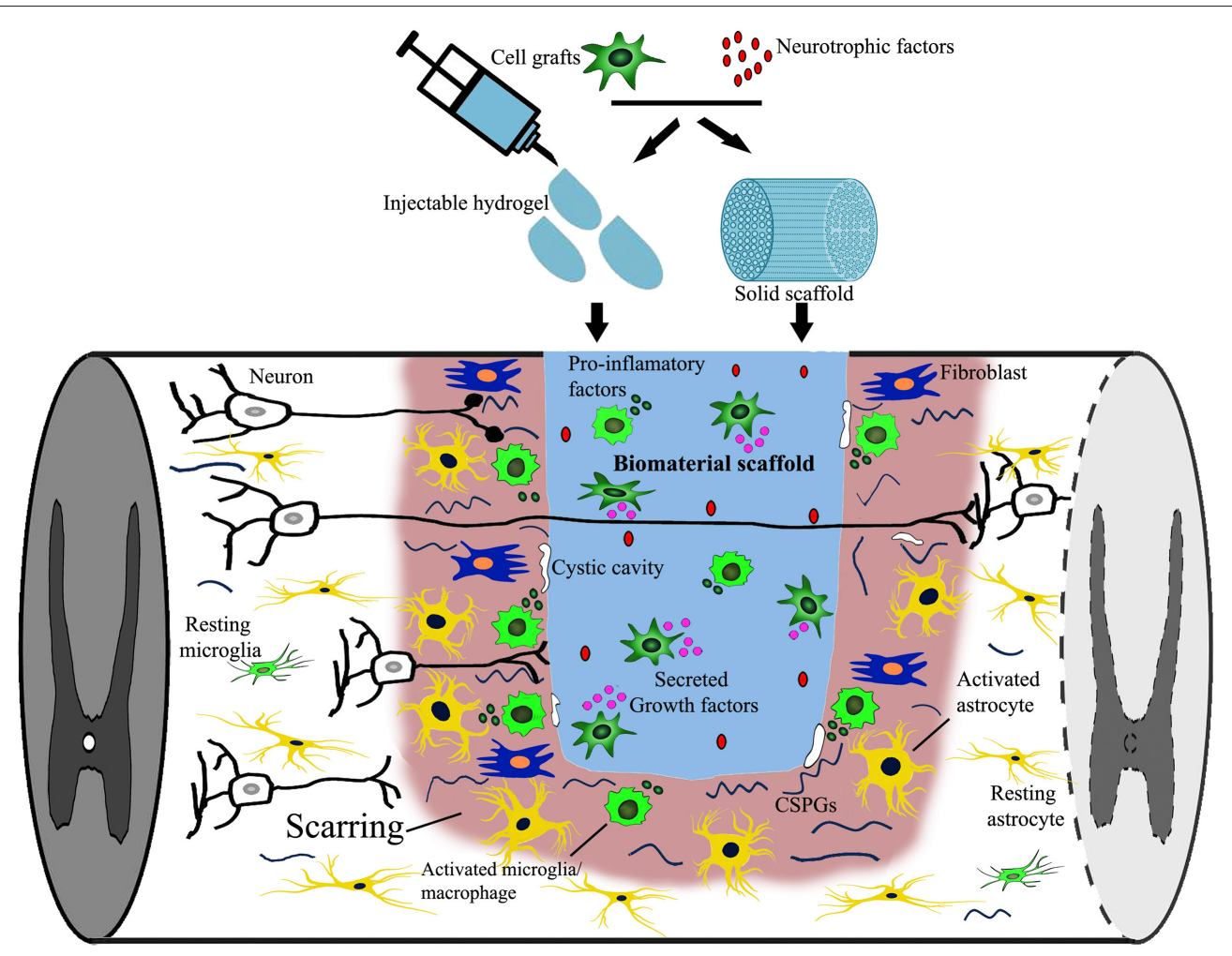

FIGURE 1 | Targets of combined biomaterial-supported cell transplantation following SCl. SCl induced neural damage leads to severed connections, tissue loss and the appearance of a cystic cavity. Combined biomaterials and cell transplantation can be used to fill the lesion cavity to provide physical support and bridge the distance that regrowing axons must traverse. Cell transplantation as well as newly introduced neurotrophic factors may provide trophic support (secreted growth factors) supporting axonal growth. An immune reaction, consisting of activated microglia, macrophages, fibroblasts and astrocytes, is elicited following injury to close off and prevent the spread of damage as well as re-establish the blood-spinal-barrier, possibly obstructing axonal regrowth. Additionally, neural injury leads to the release of growth inhibitory components [myelin debris, inflammatory cytokines, and chondroitin sulfate proteoglycans (CSPG)] that can be down regulated by either cell transplantation or the release of biomolecules into the lesion site.

cord to the host spinal injection site of SCs or if growth past the grafted SCs is possible. It was found in a $4 \mathrm{~mm}$ rat T8 complete transection that the unique combination of SC in fluid Matrigel in a PAN/PVC single channel scaffold, with OEC grafting in host parenchyma surrounding the lesion (Category II, III, and IV) and the delivery of ChABC led to functional improvement (BBB motor recovery score; up to 6 at 9 weeks vs. 2 with no treatment) (Fouad et al., 2005). Although this did not correlate to increased serotonergic fiber number caudal to the injury site but to SC myelinated fibers in the lesion site. Another approach to limit reactive astrogliosis (reduction of GFAP upregulation and CSPG expression) as well as further the intermingling of SCs and astrocytes within the graft and host tissue was the genetic modification of SCs to overexpress GDNF in a single PAN/PVC channel in a $3 \mathrm{~mm}$ T9-T10 hemisection rat model which led to enhanced SC remyelination of regenerating axons that were also aligned with protruding astrocytic extensions (Category II) (Deng et al., 2011). Additionally, SC grafting without neurotrophic factor delivery in a full T8 transection with fluid Matrigel (Category III) vs. pre-gelled Matrigel (Category I) in a PAN/PVC single channel (combined with Category II) showed greater growth of virally traced brainstem-derived (vestibular, noradrenergic, serotonergic, and reticular nuclei) axons into and up to the caudal interface where they are believed to have formed synaptic junctions with the help of newly formed supportive astrocytic protrusions (Williams et al., 2015). This significantly correlated to increased motor recovery as scored by BBB. It was proposed that fluid Matrigel led to better bridging of the host-graft interface and limited meningeal cell infiltration restricting the re-establishment of the glial limitans.

SC transplantation alone has been found to be beneficial, however the combination of SCs with biomaterials and other components provided substantial enhanced axonal regrowth and thereby functional improvement by eliciting better host-graft integration (Table 2). This includes the migration of SCs into the host parenchyma as well as astrocytic protrusions into the graft, the reduction of the glial limitans and reactive astrogliosis.

\section{Astrocytes/Glial-Restricted Progenitors/Glial-Restricted Progenitor-Derived Astrocytes}

Making up the majority of the glia cells in the CNS, astrocytes fulfill essential homeostatic and supportive functions such as 


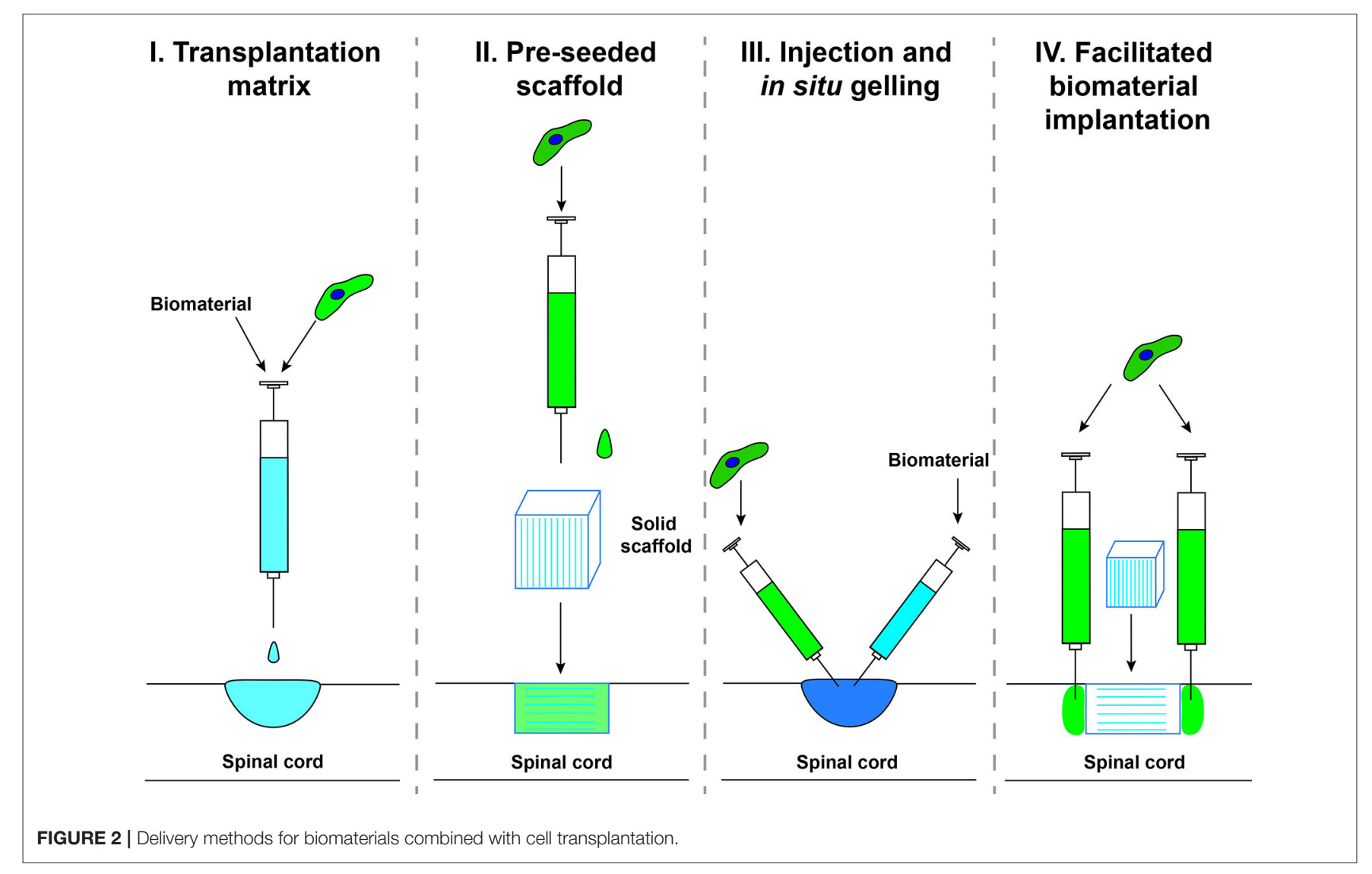

providing an organized physical matrix as well as producing neurotrophic factors for axonal remodeling and plasticity (Powell and Geller, 1999; Kimelberg and Nedergaard, 2010; Lukovic et al., 2015). In response to SCI, a dense network of reactive astrocytes physically restricts the lesion site by preventing the spread of neuroinflammation and necrosis immediately after injury (Faulkner et al., 2004; Sofroniew and Vinters, 2010; Anderson et al., 2016), although its persistence in the chronic phase may pose a physical and chemical barrier for re-growing axons (Smith-Thomas et al., 1994; Afshari et al., 2009; Sofroniew, 2009; Hellal et al., 2011; Cregg et al., 2014). Nonetheless, reactive astrogliosis is an essential part of the regenerative process as complete genetic ablation of reactive astrogliosis resulted in insufficient axonal regrowth (Faulkner et al., 2004; Anderson et al., 2016; Hara et al., 2017). Furthermore, networks of intermingled astrocytic protrusions serve as physical guidance structures for growing axons around spinal lesion sites (Silver et al., 1982; Fouad et al., 2005; Williams et al., 2015). Given these beneficial effects, astrocytes have been explored for restoration of spinal tissue integrity to mediate functional recovery (Chu et al., 2014). In line with the role of astrocytes in axonal guidance (Silver et al., 1982) and synapse formation (Baldwin and Eroglu, 2017; Liddelow and Barres, 2017) during development, it has been shown that immature (embryonic or neonatal) astrocytes provide greater regenerative bridging potential than mature astrocytes in the injured brain in both mice and rats (Smith and Silver,
1988; Smith and Miller, 1991; Filous et al., 2010). In a rat C3 fasciculus gracilis aspiration model, either oriented fetal E14 rat spinal cord tissue or astrocytes derived from E14 rat spinal cord were grafted (Bernstein and Goldberg, 1991). Over a 90 day period, the E14 derived astrocytes showed a significant increase in errors when crossing a horizontal ladder in comparison to the controls (aspiration-only), while the E14 rat spinal cord tissue graft showed a significant decrease in errors when crossing the ladder. This was found to be due to the astrocytic migration to the nucleus gracilis, where they protected neurons from denervation, increasing neuronal survival and networks only from astrocytes migrating out of the E14 spinal tissue but not from the E14 derived spinal cord astrocytes. Moreover, GFP labeled adult rat cortical astrocytes injected caudally (T11) 1 week after a T7-T8 full transection showed survival, integration and long distance migration to the lesion site and beyond 6 weeks post-transplantation (Pencalet et al., 2006).

Astrocytes are extremely heterogeneous and an adaptive cell population that vary morphologically and functionally, with phenotypes shifting with maturity, location, environmental cues and disease/injury-context (Zhang and Barres, 2010; Khakh and Sofroniew, 2015). For this reason, pre-cursors of the astrocytic and oligodendrocytic lineages (glial-restricted pre-cursors; GRPs) have been differentiated into homogenous subpopulations of astrocytes, GRP-derived astrocytes (GDA) differentiated with bone morphogenic protein 4 (BMP4, $\left.\mathrm{GDA}^{\mathrm{BMP} 4}\right)$ or with ciliary 
TABLE 2 | Schwann Cell-seeded biomaterial SCI studies.

\begin{tabular}{|c|c|c|c|c|}
\hline SCI model & Biomaterial & Cell type & Outcome & References \\
\hline Rat T8 transection & $\begin{array}{l}5 \mathrm{~mm} \text { PAN/PVC and Matrigel } \\
\text { (Category II) }\end{array}$ & $\begin{array}{l}\text { Adult rat SC + BDNF and } \\
\text { NT-3 infusion }\end{array}$ & $\begin{array}{l}\text { Increased axonal growth up to biomaterial with } \\
\text { NTFs }\end{array}$ & Xu et al., 1995a \\
\hline Rat T8 transection & $\begin{array}{l}10 \mathrm{~mm} \text { PAN/PVC and Matrigel } \\
\text { (Category II) }\end{array}$ & Adult rat SC & $\begin{array}{l}\text { Increased myelination of propriospinal and } \\
\text { sensory axons within the scaffold but not } \\
\text { exiting }\end{array}$ & Xu et al., 1995b \\
\hline Rat T8 transection & $\begin{array}{l}8 \mathrm{~mm} \text { PAN/PVC and Matrigel } \\
\text { (Category II) }\end{array}$ & Adult rat SC & $\begin{array}{l}\text { Increased myelination of propriospinal and } \\
\text { sensory axons within the scaffold but not } \\
\text { exiting }\end{array}$ & Xu et al., 1997 \\
\hline $\begin{array}{l}\text { Rat T8 } \\
\text { hemisection }\end{array}$ & $\begin{array}{l}5 \mathrm{~mm} \text { PAN/PVC and Matrigel } \\
\text { (Category II) }\end{array}$ & Adult rat SC & $\begin{array}{l}\text { Increased myelination of propriospinal and } \\
\text { sensory axons within the scaffold with some } \\
\text { exiting }\end{array}$ & Xu et al., 1999 \\
\hline $\begin{array}{l}\text { Rat C4 } \\
\text { hemisection }\end{array}$ & 2-3 mm PHB (Category II) & Adult rat SC & $\begin{array}{l}\text { Some raphespinal and sensory axonal growth } \\
\text { within the scaffold }\end{array}$ & Novikova et al., 2008 \\
\hline $\begin{array}{l}\text { Rat C4 unilateral } \\
\text { hemisection }\end{array}$ & $\begin{array}{l}2 \mathrm{~mm} \text { alginate-based anisotropic } \\
\text { capillary hydrogel (Category II } \\
\text { and IV) }\end{array}$ & Adult rat GFP-SC & $\begin{array}{l}\text { Serotonergic growth through and caudal to the } \\
\text { biomaterial up to the } 1 \mathrm{~mm} \mathrm{SC} \text { injection site }\end{array}$ & Liu et al., 2017 \\
\hline Rat T8 transection & $\begin{array}{l}4 \mathrm{~mm} \text { PAN/PVC and fluid or } \\
\text { pre-gelled Matrigel (Category I, II, } \\
\text { III and IV) }\end{array}$ & $\begin{array}{l}\text { Adult rat SC and OEC } \\
\text { surrounding the lesion }+ \\
\text { ChABC }\end{array}$ & $\begin{array}{l}\text { Increased SC myelination within the scaffold } \\
\text { with increased BBB scores }\end{array}$ & Fouad et al., 2005 \\
\hline $\begin{array}{l}\text { Rat T9-T10 } \\
\text { hemisection }\end{array}$ & 3 mm PAN/PVC (Categroy II) & $\begin{array}{l}\text { Adult rat SC expressing } \\
\text { GDNF }\end{array}$ & $\begin{array}{l}\text { Enhanced SC remyelination of regenerating } \\
\text { axons aligned with protruding astrocytic } \\
\text { extensions }\end{array}$ & Deng et al., 2011 \\
\hline Rat T8 transection & $\begin{array}{l}4 \mathrm{~mm} \text { PAN/PVC and fluid or } \\
\text { pre-gelled Matrigel (Category I, II, } \\
\text { and III) }\end{array}$ & Adult rat SC & $\begin{array}{l}\text { Greater growth of virally traced } \\
\text { brainstem-derived axons into and up to the } \\
\text { caudal interface, formed synaptic junctions } \\
\text { with the help of newly formed supportive } \\
\text { astrocytic protrusions }\end{array}$ & Williams et al., 2015 \\
\hline
\end{tabular}

neurotrophic factor $\left(\mathrm{CNTF}, \mathrm{GDA}^{\mathrm{CNTF}}\right)$. Firstly it should be noted, that after a T10 contusion in rats, transplantation of E13.5-derived GRPs alone retain their differentiation potential along the glial lineage, decrease reactive astrogliosis and CSPG expression levels as well as decrease axonal dieback of CST fibers from the lesion site and exhibit axonal growth cones (Hill et al., 2004). Injection of rat or human-derived GRPs or GDA ${ }^{\text {CNTF }}$ or $\mathrm{GDA}^{\mathrm{BMP} 4}$ into a rat C4/C5 dorsal column SCI model equally supported regeneration of ascending sensory tracts into the lesion site but not out (Haas et al., 2012; Haas and Fischer, 2013). Similarly, in a T10 moderate contusion in athymic rats human GRP and GDA ${ }^{\mathrm{BMP} 4}$ produced astrocytes at the lesion site that migrated out of the lesion and led to decreased cystic cavitation and reactive astrogliosis as well as increased sprouting. However, this did not lead to any significant changes in thermal and mechanical sensitivity or motor recovery (GridWalk) compared to controls (Jin et al., 2011). Several studies have been undertaken with GDA ${ }^{\text {BMP4 }}$ showing increased growth of ascending sensory neurons of the dorsal columns into and through the lesion site, increased preservation of rubrospinal tracts and decreased misstep rates on the GridWalk (Davies et al., 2006; Fan et al., 2013; Wu et al., 2013), whereas GDA ${ }^{\text {CNTF }}$ has not shown any functional benefit or axonal regeneration but has led to allodynia as well as thermal and mechanical hyperalgesia (Davies et al., 2008, 2011).

Given that previous work with astrocytic grafting shows a lack of regenerative potential, astrocytes, themselves may be better suited as living scaffolds, linearly guiding axons in and out of biomaterials. Comparison of cultured astrocytes on either anisotropic poly(L-lactic acid) (PLLA) fibers or isotropic PLLA films revealed linear orientation of astrocytes to the anisotropic substrate, which provided a guidance matrix for the cultured astrocytes and dorsal root ganglia (DRG) neurons (Zuidema et al., 2015). When tethered self-aligning collagen gels aligned both the biomaterial with astrocytes this lead to significant increased growth of adult rat DRG in the aligned portions compared to the unaligned portions (East et al., 2010). Furthermore, alginate-based anisotropic capillary hydrogels lead to linear migration of astrocytes along capillary channels that are supportive of axonal outgrowth from neonatal rat entorhinal cortex and spinal cord slice cultures (Pawar et al., 2015b). Early studies already demonstrated that the implantation of fetal (E16 or E18) spinal cord astrocyte-seeded Millipore pennants (Category II) into a L5 dorsal root fiber crush model promoted substantial axonal growth into spinal gray matter tracts (Kliot et al., 1990). Additionally, implantation of neonatal rat cortical astrocytes situated in a Gelfoam matrix (Category II) or transplantation of astrocytes alone into a rat L3 dorsal lateral hemisection reduced host astrogliosis, scar formation and slightly increased density of neurofilament (NF) positive fibers when compared to controls (transplantation of Hanks buffered saline or implantation of empty Gelfoam) (Wang et al., 1995). While it is unclear which method has a greater beneficial effect, it was noted that the Gelfoam delayed the migration of the astrocytes 
from the lesion site and that cell-seeded Gelfoam appeared to be better integrated into the lesion site than Gelfoam alone. Fast blue labeled neonatal (P3) neocortical astrocytes embedded for retention in a collagen gel (modified Category I/II) were implanted into a $2 \mathrm{~mm}$ spanning T8 dorsal hemisection leading to increased neurofilament positive regenerating fibers within the implant, aligned along processes of the labeled astrocytes (Joosten et al., 2004). However, a minimal growth of biotinylated dextran amine (BDA) labeled CST fibers into the rostral edge of the gel scaffold was observed, although did not exit the lesion site. Limited improvements were observed in fine motor movements with the BBB subscore and Catwalk, analyzing hindlimb stride length and swing duration parameters, but not in the overall locomotor BBB score or Gridwalk analysis, when compared to collagen gel implantation alone. These changes may be due to the other fiber tracts not labeled in this study such as serotonergic fibers. To increase continuous tissue integrity across a large lesion site, Hoechst labeled P1 neonatal rat astrocytes were aligned on PLA/PLA-b-PEO matrices and implanted into a $2 \mathrm{~mm}$ T11/T12 dorsal hemisection with injection of astrocytes $1 \mathrm{~mm}$ both rostral and caudal of the lesion site (Category II and IV) (Deumens et al., 2006b). An increased BDA-labeled CST was observed up to the lesion site with astrocytes than controls (empty lesion site with media injected into the host parenchyma), however growth into the biomaterial was not observed likely due to the lack of astrocyte survival within the matrix. Naturally, no functional benefits were observed by the $\mathrm{BBB}$ locomotor score or stride length performed by Catwalk gait analysis.

Grafting of astrocytes, GRPs and GDAs into SCI lesions has shown their ability to reduce reactive astrogliosis, support neuronal survival and a minimal amount of axonal growth into but rarely beyond the lesion site. However, the regenerative potential of astrocytic grafting alone appears to be limited possibly due to their extensive migration away from the lesion. The combination of astrocytes with biomaterials delays their migration from the lesion site and enhances the host integration of the biomaterial by supplying directed growth of the axons along aligned astrocytes into the biomaterial. What remains to be examined is the use of GRPs or GDA ${ }^{\text {BMP4 }}$, both of which had greater axonal support potential alone than neonatal astrocytes, in combination with biomaterials to not only enhance biomaterial integration through tissue continuity across the lesion but also possibly increase axonal growth. For combinatorial work with astrocytes (Table 3) likely other factors such as neurotrophic factors will need to be utilized to increase axonal regrowth beyond the lesion site.

\section{Olfactory Ensheathing Cells}

Acquired from the olfactory bulb and mucosa, OECs represent an intermediary glial cell type between SCs and astrocytes (Granger et al., 2014). OECs express both the astrocytic marker GFAP (glial fibrillary acidic protein) and the SC marker p75-NTR (p75neurotrophic factor receptor), however microarray profiling puts OECs in closer genetic proximity to SCs (Vincent et al., 2005). Similar to SCs, OECs have been shown to remyelinate injured axons (Li et al., 1997) and produce neurotrophic factors (Sasaki et al., 2006), although unlike SCs, OECs intermingle with host astrocytes to form supportive physical pathways presenting a growth inducing cellular and molecular substrate (Lakatos et al., 2000; Li et al., 2005). A review of OEC transplantation studies following SCI listed 41 studies showing beneficial effects, ranging from axonal regrowth, tissue sparring, angiogenesis, migration and remyelination, yet 13 studies showed no effects (Franssen et al., 2007). Several studies directly compared the transplantation of OECs or SCs and consistently observed benefits from SCs in axonal regeneration rather than OECs (Takami et al., 2002; Pearse et al., 2007). Furthermore, various OEC extraction protocols have led to varying purity which likely contributes to the observed high variability of effects of OECs in SCI studies (Ramon-Cueto and Nieto-Sampedro, 1992; Vincent et al., 2003; Rizek and Kawaja, 2006; Novikova et al., 2011).

In an attempt to further bridge nerve injuries, biomaterials have been combined with OECs to support axonal growth. OECs show a higher compatibility in terms of attachment and proliferation as well as nerve outgrowth on different biomaterials such as PLGA (Li et al., 2010), collagen (Wang et al., 2006), alginate and Matrigel scaffolds (Novikova et al., 2006) when combined with components of the ECM in a peripheral nerve injury model or in vitro. In rats a $2 \mathrm{~mm}$ long T11/T12 dorsal hemisection was filled with aligned OEC/ONF (olfactory nerve fibroblasts) - poly(D,L)-lactide biomatrix bridges (Category II) accompanied by Hoescht-labeled OEC/ONF injections surrounding the lesion site $(1 \mathrm{~mm}$ rostral and caudal, Category IV), which led to migration of these cells up to the biomatrix but not within nor did the cells seeded within the biomatrix survive well, possibly due to the degradation of the biomatrix (Deumens et al., 2006a). All the same, this cell-seeded biomaterial implantation led to increased axonal growth into the lesion site than biomaterial alone, excluding CST growth, coupled with minimally increased gait parameters of stride length and swing speed (CatWalk) but no increased locomotor recovery (BBB). While the cause of this improvement was not specifically examined it was hypothesized to be due to other descending or ascending axonal tracts than the CST or the formation of new intraspinal relays. The use of OEC-seeded collagen-based multi-channel 3D matrices (Category II) in a $2 \mathrm{~mm}$ spanning T13 unilateral hemisection in rats showed no improvement on motor function (CatWalk) or alleviation of allodynia (von Frey hair filament test), furthermore axonal regrowth or scaffold integration was not examined (Deumens et al., 2013). Most recently, it was found that OEC-seeded PLGA scaffolds (Category II) in a $2 \mathrm{~mm}$ T9/T10 complete transection rat SCI model increased motor recovery (BBB score of 9 vs. 6 of controls and more successful crossings of an inclined plane) which correlated with increased axonal preservation and decreased astrogliosis reflecting neuroprotection as the underlying mechanism (Wang et al., 2017). As previously mentioned, the combination of OEC injection surrounding a PAN/PVC SC-seeded Matrigel implant in a full thoracic transection led to long distance growth both of ascending and descending axonal tracts into and through the lesion site (Ramon-Cueto et al., 1998; Fouad et al., 2005).

These studies (Table 4) show that OEC when injected surrounding the biomaterial help with growth of axons up to the lesion site, however they do not appear to migrate out from 
TABLE 3 | Astrocyte-seeded biomaterial SCl studies.

\begin{tabular}{|c|c|c|c|c|}
\hline SCI model & Biomaterial & Cell type & Outcome & References \\
\hline $\begin{array}{l}\text { Rat L5 dorsal root } \\
\text { fiber crush model }\end{array}$ & Millipore pennants (Category II) & $\begin{array}{l}\text { Rat fetal (E16 or E18) spinal } \\
\text { cord astrocytes }\end{array}$ & $\begin{array}{l}\text { Promoted substantial axonal growth into spinal } \\
\text { gray matter tracts }\end{array}$ & Kliot et al., 1990 \\
\hline $\begin{array}{l}\text { Rat L3 dorsal } \\
\text { lateral hemisection }\end{array}$ & Gelfoam matrix (Category II) & $\begin{array}{l}\text { Neonatal rat cortical } \\
\text { astrocytes }\end{array}$ & $\begin{array}{l}\text { Reduced host astrogliosis, scar formation, and } \\
\text { slightly increased density NF }\end{array}$ & Wang et al., 1995 \\
\hline $\begin{array}{l}\text { Rat T8 dorsal } \\
\text { hemisection }\end{array}$ & $\begin{array}{l}2 \mathrm{~mm} \text { Collagen gel (modified } \\
\text { Category I/II) }\end{array}$ & $\begin{array}{l}\text { Neonatal rat (P3) neocortical } \\
\text { astrocytes }\end{array}$ & $\begin{array}{l}\text { Increased NF within biomaterial aligned along } \\
\text { astrocytes, minimal CST growth into rostral end } \\
\text { without exiting biomaterial, improvements in } \\
\text { BBB sub-score and Catwalk stride length and } \\
\text { swing duration }\end{array}$ & Joosten et al., 2004 \\
\hline $\begin{array}{l}\text { Rat } \mathrm{T} 11 / \mathrm{T} 12 \\
\text { dorsal hemisection }\end{array}$ & $\begin{array}{l}2 \mathrm{~mm} \text { PLA/PLA-b-PEO matrices } \\
\text { (Category } \| \text { and IV) }\end{array}$ & $\begin{array}{l}\text { P1 neonatal rat astrocytes, } \\
1 \mathrm{~mm} \text { rostrocaudal } \\
\text { injections }\end{array}$ & $\begin{array}{l}\text { Increased CST growth up to the lesion site, } \\
\text { poor astrocyte survival within matrix }\end{array}$ & Deumens et al., 2006b \\
\hline
\end{tabular}

or into the biomaterial to increase tissue continuity, decrease cavitation surrounding the biomaterial or survive well when seeded in a biomaterial (this may have been due to biomaterial integrity, which should be re-examined), therefore currently at this time, OECs alone may not be the best candidate for combination with biomaterials.

\section{Bone Marrow Mesenchymal Stem Cells}

BMSCs are a widely used cell type for transplantation studies that can be easily isolated from a bone marrow aspiration and extensively expanded in culture, which makes autologous transplantation possible (Mendonca et al., 2014). BMSCs not only differentiate into a variety of mesodermal lines but also have been described to differentiate into microglia, oligodendrocytes and macrophages when transplanted into the spinal cord (Corti et al., 2002; Cizkova et al., 2006). However, the phenomenon of transdifferentation into neural cells has been challenged ( $\mathrm{Lu}$ et al., 2004) and is likely not relevant for beneficial effects observed after SCI transplantation. More importantly for use in SCI, BMSCs can fill the lesion cavity and produce ECM components, thereby providing structural support for growing axons (Kim et al., 2013; Volpato et al., 2013). Furthermore, BMSCs display anti-inflammatory properties by producing immunoregulatory cytokines (interleukins and transforming growth factor- $\beta$ ) (Bartholomew et al., 2002; Noh et al., 2016) and interactions with host immune cells (Deans and Moseley, 2000; Zhang et al., 2016). In this context, transplantation of BMSCs diminished reactive astrogliosis and microglial activation (Abrams et al., 2009; Ruff et al., 2012). In addition to cytokines, BMSCs secrete permissive growth factors (Chen et al., 2002; Ohta et al., 2004; Kim et al., 2013; Ritfeld et al., 2015), although at relatively low levels. To enhance the role of BMSC paracrine secretion on axonal regeneration, genetically modified BMSCs have been used in various studies to deliver neurotrophic factors (Gong et al., 2015; Ritfeld et al., 2015; Zhu et al., 2015; Brock et al., 2016) in experimental SCI models. Although MSCs have been shown in a meta-analysis of relevant pre-clinical studies to increase the BBB score of thoracic SCI rats on average by 3.9 points the relevance of this increase has to be treated with caution due to the lack of a baseline from which locomotor activity is assessed (Oliveri et al., 2014).
While biomaterials fill the lesion site, they still require tissue continuity to allow for axonal growth into them. To this end, BMSC-seeded in porous but undirected 2-hydroxyethyl methacrylate (HEMA) or 2-hydroxypropyl methacrylamide (HPMA) scaffolds (Category II) implanted in a unilateral hemisection increased neurofilament positive axonal growth into the hydrogels (Sykova et al., 2006). Additionally, growth permissive BDNF expressing BMSCs were seeded into multicomponent fiber bundled agarose scaffolds (Category II) after a $2 \mathrm{~mm}$ long T3 complete transection which led to increased growth of both descending (raphespinal and reticulospinal tracts) as well as ascending sensory fibers into the lesion site, far greater than GFP expressing BMSC-seeded biomaterials (Gao et al., 2013). To confirm this observation, BMSCs expressing BDNF seeded in a $2 \mathrm{~mm}$ alginate-based anisotropic capillary hydrogel (Category II) in a rat C5 unilateral hemisection enhanced directed axonal regrowth in comparison to hydrogels seeded with BMSCs alone (Gunther et al., 2015a,b). Both studies observed a significant increase of BDNF-driven axonal growth into and through the biomaterial but not exiting it nor did either study examine behavioral outcomes. By co-culture with NT3 overexpressing SCs in a 3D gelatin sponge scaffold, genetically modified BMSCs overexpressing Neurotrophic Receptor Tyrosine Kinase 3 (TrkC) differentiated into cells exhibiting neuronal features (neurofilament and postsynaptic density 95) (Category II), which were implanted into a rat $2 \mathrm{~mm}$-wide T9-T10 transection SCI (Zeng et al., 2015). This treatment led to enhanced axonal growth throughout the biomaterial, synaptic association of these cells with mostly serotonergic neurons and some CST axons (electron microscopy), the upregulation of c-Fos in the grafted as well as host lumbar spinal cord cells in response to motor cortex stimulation and the improvement of locomotor function (BBB score of 8 for the cell-seeded biomaterial vs. 3 for biomaterial alone). The biomaterial alone vs. control SCI alone was not significantly different in axonal growth or functional parameters examined.

Overall, an added value of the combinatorial therapy with BMSCs and biomaterials is observable (Table 5) over biomaterials alone by increased ingrowth into scaffolds (Gao et al., 2013; Zeng et al., 2015), however it appears to not be 
TABLE 4 | OEC-seeded biomaterial SCI studies.

\begin{tabular}{|c|c|c|c|c|}
\hline SCI model & Biomaterial & Cell type & Outcome & References \\
\hline $\begin{array}{l}\text { Rat } \mathrm{T} 11 / \mathrm{T} 12 \\
\text { dorsal hemisection }\end{array}$ & $\begin{array}{l}2 \text { mm poly(D,L)-lactide biomatrix } \\
\text { (Category II and IV) }\end{array}$ & $\begin{array}{l}\text { OEC/ONF within and } 1 \mathrm{~mm} \\
\text { rostrocaudal injections }\end{array}$ & $\begin{array}{l}\text { Migration of cells up to but not within biomatrix, } \\
\text { poor cell survival within biomatrix, increased } \\
\text { axonal growth excluding CST, increased stride } \\
\text { length and swing speed }\end{array}$ & Deumens et al., $2006 a$ \\
\hline $\begin{array}{l}\text { Rat T13 unilateral } \\
\text { hemisection }\end{array}$ & $\begin{array}{l}2 \mathrm{~mm} \text { collagen-based multi-channel } \\
\text { 3D matrices (Category II) }\end{array}$ & OEC & $\begin{array}{l}\text { No improvement in CatWalk gait analysis or } \\
\text { alleviation of allodynia }\end{array}$ & Deumens et al., 2013 \\
\hline $\begin{array}{l}\text { Rat T9/T10 } \\
\text { complete } \\
\text { transection }\end{array}$ & 2 mm PLGA scaffolds (Category II) & OEC & $\begin{array}{l}\text { Increased BBB score and crossing of inclined } \\
\text { plane, increased axonal preservation, } \\
\text { decreased astrogliosis }\end{array}$ & Wang et al., 2017 \\
\hline
\end{tabular}

sufficient enough growth for functionally relevant improvements alone without being coupled with other therapies such as neurotrophin overexpression or co-culture with other cell types.

\section{Neural Stem and Progenitor Cells}

NSPCs can be generated from embryonic, fetal or adult CNS tissues and bear the unique feature of extensive self-renewal in vivo as well as differentiation into any desired neural cell type (Iwanami et al., 2005). NSPCs represent a promising and powerful tool to replace damaged tissue and bridge the lesion cavity by providing a cellular matrix, tissue replacement through targeted differentiation, neuroprotection and trophic support, (Assinck et al., 2017; Vismara et al., 2017). More recently, fetal spinal cell grafting after SCI is performed with growth factor trophic support and a fibrin matrix (Category I) to enhance cell survival and retention of the cells at the lesion site (Lu et al., 2012; Kadoya et al., 2016; Robinson and Lu, 2017). This encouraged the most extensive neuronal growth from NSPCs observed in a SCI (T3 full transection, CST and right quadrant lesions or C4 CST lesion) with resulting functional improvement in either hindlimb function (BBB score 6.5 vs. 1.5 $\mathrm{BBB}$ score for the lesion-only controls at 6 weeks postgrafting) or forelimb function (the staircase task with increased level reached and pellets eaten in the graft vs. lesion alone) or increased electrophysiology between grafted cells and CSTs through the creation of functional neuronal relays. Generally in the absence of growth factors and matrices, neural restricted progenitors (NRPs) and GRPs survive acute SCI grafting better than do multipotent neuroepithelial (NEP) stem cells, however delayed grafting of the fetal or embryonic NSPCs does allow for better survival and filling of the lesion site (Theele et al., 1996; Lepore et al., 2004; Iwanami et al., 2005; Lu et al., 2012, 2014a). It was found in mouse C4-CST lesions that grafted GRPs with NRPs or NPCs alone had surviving neurons and glia that filled the lesion site and supported CST regenerative growth, however grafted GRPs alone failed to do so (Kadoya et al., 2016). Moreover, it was found that adult NSPCs are incapable of filling the lesion cyst after transplantation into the injured spinal cord (Vroemen et al., 2003; Sandner et al., 2013). Another study has found that transplantation of NSPCs that differentiate primarily into astrocytes in response to SCI leads to the development of thermal and mechanical allodynia (Macias et al., 2006). Astrocytes do support axonal growth, however the type of growth they support may be determined by their dysregulation by the surrounding injury environment hence the development of astrocytic-dependent pain (Falnikar et al., 2015). Protection from direct contact with the lesion environment may provide NSPC-derived astrocytes with a different outcome (Cao et al., 2002).

Following SCI, the overall aim of seeding NSPCs into biomaterial scaffolds is to increase CNS regeneration by (1) improving the survival and potential differentiation of grafted NPSCs into mature cells to preserve tissue integrity by serving as a supportive matrix and (2) decreasing the host response to the biomaterial implantation by reducing inflammation and fibroglial scarring (Reeves and Keirstead, 2012; Bellenchi et al., 2013; Matsui et al., 2014). NSPCs derived from the subventricular zone (SVZ) of adult rats were incorporated into a PDGFA-conjugated hyaluronan and methyl cellulose-based hydrogel blend (HAMC) (modified Category III/IV) and grafted 9 days post-clip T2 compression injury $1 \mathrm{~mm}$ rostral and $1 \mathrm{~mm}$ caudal to the injury site (Mothe et al., 2013). Even though cell survival was increased 1 week post-grafting, hardly any cells survived after 8 weeks when transplanted alone or in combination with the hydrogel. Nevertheless, sparing of host oligodendrocytes and neurons was enhanced, positively affecting functional outcomes for fine motor (horizontal ladder) changes but not gross motor skills (BBB). Murine NSCs (clone C17.2) were either seeded on a $4 \mathrm{~mm}$ oriented porous PLGA scaffold (Category II) or transplanted alone in comparison to naïve PLGA scaffolds or no treatment controls in a rat T9/T10 lateral hemisection model (Teng et al., 2002). To avoid additional neuroprotective effects no immunosuppression was used (Guo et al., 2001). Implanted scaffolds increased cell survival over transplanted cells alone. The greatest tissue preservation (white matter sparing) was served by the cell-seeded scaffolds followed by the scaffold alone, cells alone and finally the no treatment group. In addition to increased NF positive axonal growth within the lesion site, the scaffolds with or without cells had increased sensorimotor cortex traced BDA fibers both rostral and caudal to the lesion site co-labeled with growth-associated protein $43 \mathrm{kDa}$ (GAP-43, an axonal regenerating marker) rostral to the lesion site, which was not observed in the cell transplantation or no treatment control groups. Both tissue preservation and regenerating fibers are thought to contribute to the increased motor recovery seen in the cell-seeded scaffold group (BBB score 11 vs. BBB score 
TABLE 5 | BMSC-seeded biomaterial SCI studies.

\begin{tabular}{|c|c|c|c|c|}
\hline SCI model & Biomaterial & Cell type & Outcome & References \\
\hline $\begin{array}{l}\text { Rat unilateral } \\
\text { hemisection }\end{array}$ & $\begin{array}{l}\text { 2-hydroxyethyl methacrylate } \\
\text { (HEMA) or 2-hydroxypropyl } \\
\text { methacrylamide (HPMA) } \\
\text { scaffolds (Category II) }\end{array}$ & BMSC & Increased neurofilament positive axonal growth & Sykova et al., 2006 \\
\hline Rat T3 transection & $\begin{array}{l}2 \text { mm multi-component fiber } \\
\text { bundled agarose scaffolds } \\
\text { (Category II) }\end{array}$ & $\begin{array}{l}\text { BMSC-BDNF and } \\
\text { BMSC-GFP }\end{array}$ & $\begin{array}{l}\text { Increased growth of raphespinal, reticulospinal } \\
\text { tracts and sensory fibers into but not exiting } \\
\text { scaffold }\end{array}$ & Gao et al., 2013 \\
\hline $\begin{array}{l}\text { Rat C5 unilateral } \\
\text { hemisection }\end{array}$ & $\begin{array}{l}2 \mathrm{~mm} \text { alginate-based anisotropic } \\
\text { capillary hydrogel (Category II) }\end{array}$ & $\begin{array}{l}\text { BMSC-BDNF and } \\
\text { BMSC-GFP }\end{array}$ & $\begin{array}{l}\text { Enhanced directed axonal regrowth into but } \\
\text { not exiting hydrogels }\end{array}$ & Gunther et al., 2015a,b \\
\hline $\begin{array}{l}\text { Rat T9-T10 } \\
\text { transection }\end{array}$ & $\begin{array}{l}2 \mathrm{~mm} 3 \mathrm{D} \text { gelatin sponge scaffold } \\
\text { (Category II) }\end{array}$ & $\begin{array}{l}\text { co-culture SC-NT-3 and } \\
\text { BMSC-TrkC }\end{array}$ & $\begin{array}{l}\text { Enhanced axonal growth throughout the } \\
\text { biomaterial, synaptic association of these cells } \\
\text { with serotonergic neurons and some CST } \\
\text { axons, upregulation of c-Fos in the grafted as } \\
\text { well as host lumbar spinal cord cells and } \\
\text { improvement of BBB score }\end{array}$ & Zeng et al., 2015 \\
\hline
\end{tabular}

8 for scaffold alone, and BBB score $\sim 6$ for cells alone or no treatment controls at 70 days). Implanted in a rat $2 \mathrm{~mm}$ full T8/T9 transection, PLGA scaffolds (with 7 longitudinal channels, each with a diameter of $660 \mu \mathrm{m}$ ) were seeded with rat E14.5 NSCs (telencephalon/diencephalon) or adult rat SCs suspended in Matrigel (Category II) or no cells (Olson et al., 2009). Even though seeded PGLA scaffolds increased axonal fibers throughout the scaffold after 4 weeks it did not lead to increased motor recovery in such a severe lesion (BBB score $\sim 1)$. An oriented PLGA scaffold filled with a macroporous 4-arm poly(ethylene glycol) (PEG) hydrogel and coated with Poly(L-lysine) (PLL) was seeded with endothelial cells and NSPCs (from the SVZ zone of P1 GFP rats) in a rat T9-T10 lateral hemisection (Category II) (Rauch et al., 2009). This yielded a several fold increase in functional blood vessels over groups with either cell type seeded alone, biomaterial alone or lesion alone, recreating the blood spinal barrier. At 8 weeks post-injury, this also led to differentiation of the seeded NSPCs as well as increased NF staining at the host/graft interface and lesion epicenter coupled with GAP-43 staining of regenerating axons not colocalizing with GFP transplanted cells but with host axons. In another study, $10 \mathrm{~mm}$ long laminin-coated chitosan channels were seeded with either adult brain or spinal NSPCs (Category II) in a T8 transection rat model which led to long-term survival (14 weeks), differentiation (astrocytes and oligodendrocytes), decreased cyst formation and increased tissue bridge formation compared to empty scaffold or no scaffold (Nomura et al., 2008). Not surprisingly given the lesion size, no change in functional improvement occurred nor did any BDA labeled CST axons enter the channel. Implantation of adult neurosphere NSPC-seeded un-coated chitosan channels (Category II) 3 weeks post-T8 clip compression SCI in rats revealed a 5-fold increase in cell survival compared to NSPC grafting alone, however no tissue bridging or functional change was observed at 9 weeks (BBB scores ranging between 9 and 11) (Bozkurt et al., 2010). Non-proliferating NSPCs differentiated $\sim 50 \%$ into oligodendrocytes, with very few differentiating into astrocytes or neurons, and $\sim 50 \%$ remaining undifferentiated in the NSPC-seeded chitosan channels. NSPC grafting alone had greater number of oligodendrocytes and fewer undifferentiated cells, however overall cell survival was less than those seeded in channels.

To further improve these beneficial effects, either neurotrophic factors were overexpressed or bioactive molecules were conjugated into scaffold backbones. In an oriented macroporous PLGA scaffold seeded with rat P1-P3 hippocampal NSCs infected with NT-3 or TrkC (co-culture), naïve NSCs or unseeded PLGA were implanted into a $2 \mathrm{~mm}$ T10 full transection (Category II) (Du et al., 2011). Immunohistology and electron microscopy (EM) confirm differentiation into mature neurons (MAP2) forming synapases (PSD95) in the co-culture-seeded biomaterial group. This treatment also specifically led to the preservation of neurons in the sensorimotor cortex, red nucleus (descending tracts) and Clarke's nuclei (ascending tracts) as well as a significant increase in NF positive staining rostral and caudal to the scaffold and in the epicenter. Moreover, at 8 weeks post-injury this increased the motor recovery from 1.5 BBB score in the PLGA unseeded group to 3.5 in the NSC + PLGA group and 8.5 in the co-culture NT-3/TrkC-NSC + PLGA group. A similar study published at the same time in a T10 full transection implanted $2 \mathrm{~mm}$ Gelfoam scaffolds seeded with co-cultured NT-3-SC and TrkC-NSC (Category II) compared to Gelfoam alone, with NSC, with LacZ-SC + LacZ-NSC, with NT-3-SC + NSCs (Wang et al., 2011). The combination of NT-3-SC + TrkC-NSC seeded Gelfoam led to increased motor improvements (BBB 7.6 vs. NSC Gelfoam 1.6 and SCI alone 0.5, 60 days after injury) along with increased cortical somatosensory evoked potentials and cortical motor evoked potentials. This treatment also led to increased neuronal differentiation (MAP2), increased cell survival of internal pyramidal layer, red nuclei (descending tracts) and Clarke's nucleus (ascending tracts), increased SC myelination (EM) and synapse formation (EM and pre/post-synapse markers). While it needs to be further examined, the study indicates synapse formation at the epicenter of the lesion between transplanted NSCs and regenerating host axons leading to the enhanced functional recovery. A human immortalized NSC line (F3) was seeded with the addition of NT-3 
expression in poly( $\varepsilon$-caprolactone) (PCL) scaffolds (Category II) in rat lateral T7-T8 hemisection which led to increased differentiation in neurons and oligodendrocytes, white matter sparing, regenerative markers (GAP-43 and synaptotagmin) by ELISA and Western blot analysis caudal to the lesion, than the F3-PCL group (Hwang et al., 2011). This correlated with increased motor recovery (BBB score up to 15 for the F3-NT-3PCL, 13 for the F3-PCL, 11 for PCL and 10 for lesion alone as well as significantly less errors on a GridWalk at 4 and 7 weeks, errors decreasing with each additional treatment). Moreover, the addition of Chondroitinase $\mathrm{ABC}$ reduced CSPGs and increased motor recovery of the F3-NT-3-PCL group, including motor evoked potentials. Another study was conducted using rat neonatal NPCs (telencephalons) embedded into a $4 \mathrm{~mm}$ porous collagen and collagen-cetuximab scaffolds conjugated with a neutralizing antibody of epidermal growth factor receptor (EGFR, to block downstream inhibitory Nogo receptor signaling) (Koprivica et al., 2005), reducing the microglial inflammatory response (Qu et al., 2012) and reactive astrogliosis (Li et al., 2011) as well as increasing neuronal over astrocytic differentiation (Ayuso-Sacido et al., 2010) in a rat T13-L2 lateral hemisection (Category II) (Li et al., 2013). Here, neuronal differentiation was increased, whereas astrocytic differentiation was decreased and modest functional improvement was observed (BBB score 6 from 2 of empty collagen scaffold control and increased angle on inclined plane between seeded scaffolds vs. empty scaffolds).

In move toward clinical application both canine and African green monkey models of SCI (a $5 \mathrm{~mm}$ T11 lateral hemisection and a $10 \mathrm{~mm}$ T9/T10 lateral hemisection, respectively) have been developed to test the use of coated and uncoated PLGA scaffolds seeded with human NSC lines expressing NT-3 or not (Kim et al., 2010; Pritchard et al., 2010). While these studies found grafting to be feasible more work needs to be done to understand the efficacy of the treatments.

The combination of biomaterial scaffolds with NSPCs (Table 6) clearly has an enhanced effect on cell survival and to a lesser extent on differentiation as well as decreased cyst formation and increased tissue preservation. Many studies observed increased tissue bridging and regenerating axonal growth, however this was not always coupled with increased functional improvement. Importantly, with the addition of other factors, such as growth factors and biomolecules within the biomaterial, there was a greater increase in axonal growth into the scaffold, along with mature neuronal synapse formation with host neurons and supposed neuronal relays leading to functional improvements. Here, the combination of biomaterials with NSPCs (and other treatments) demonstrates a greater effect than NSPC transplantation alone after a SCI. Interestingly, this effect appears to be greater than the combination of biomaterials with other cell types.

It should be noted that while not covered in this review that both the embryonic stem (ES) cells and induced pluripotent stem cells (iPSCs) are viable cellular candidates for biomaterialsupported cell transplantation. Both ES cells and iPSCs are capable of becoming any cell type and with this ability comes the potential for undifferentiated proliferation and tumorigenesis (Assuncao-Silva et al., 2015), which may be further enhanced by combination with a biomaterial. While ethical concerns constrict the use of ES cells and find benefit in the iPSCs which can be made autologously from a patient's skin sample, there still remains the concern of viral expression to induce pluripotency as well as the time frame it takes from collection of the patient sample until the iPSC or differentiated iPSC is produced. In addition, neuronal differentiation of iPSCs is more complicated than ES cells ( $\mathrm{Hu}$ et al., 2010). In comparison to the work done with NSPCs and biomaterials in animal models, work done combining ES cells or iPSCs with biomaterials is more limited at this time (Hatami et al., 2009; Lu et al., 2014b; McCreedy et al., 2014).

\section{CHALLENGES FACING CELL-SEEDED BIOMATERIAL STRATEGIES}

More single application treatments (SCs, OECs, BMSCs, biomaterial scaffolds) are slowly making their way into clinical trials (Mackay-Sim et al., 2008; Kumar et al., 2009; Karamouzian et al., 2012; Tabakow et al., 2013; Amr et al., 2014; Mendonca et al., 2014; Theodore et al., 2016; Xiao et al., 2016; Anderson et al., 2017), however combinatory treatments are still primarily pre-clinical. Currently the field of cell-seeded biomaterials is in its infancy and targeting proof of concept experiments. If an experimental combination moves from in vitro to in vivo and shows substantial axonal regeneration linked to functional recovery then we can start addressing questions of clinical relevance. For example, many of the studies presented here were drastic hemisection or full transection injury models vs. the human relevant contusion/compression models (Devivo et al., 2002). In addition, many are thoracic lesions vs. the more common cervical lesions observed in SCI patients (Singh et al., 2014). In this thread, most studies work on acute or subacute SCI, as chronic SCI is time consuming and challenging for a treatment that has not already shown some promise in the acute phase. However, patients recruited for such clinical trials would likely be stable chronic patients who are no longer spontaneously recovering following the reduction of inflammation or other secondary damage, thus the obstacles faced in their lesion microenvironment would be different from that of the acute or subacute phase and must be taken into consideration.

In regards to cell transplantation in humans, autologous cells would be ideal, otherwise allogenic samples from other individuals may require long-term immunosuppression which will create other obstacles that need to be overcome. For some autologous cell types, longer periods of culturing are required to improve purity, quantity or differentiation which make immediate transplantation impossible in sub-acute SCI where much of the current preclinical work has been conducted (Mertens et al., 2016; Vismara et al., 2017).

Great progress has been made in both the fields of tissue engineering (cell purification procedures, autologous cell culture, culture methods increasing viability and genetic modifications) as well as biomaterial sciences (stability, combatibility, purity, self-assembling scaffolds, consistent capillary scaffolds, and biomolecule delivery), creating solutions (linear directed growth, increased viability, increased tissue stablity, decreased immune 
TABLE 6 | NSPC-seeded biomaterial SCl studies.

\begin{tabular}{|c|c|c|c|c|}
\hline SCI model & Biomaterial & Cell type & Outcome & References \\
\hline Rat T3 transection & Fibrin matrix (Category I) & $\begin{array}{l}\text { Rat E14 fetal spinal cells } \\
\text { with cocktail of growth } \\
\text { factors }\end{array}$ & $\begin{array}{l}\text { Neuronal differentiation and growth of NSPCs, } \\
\text { extensive axonal growth (serotonergic) into the } \\
\text { matrix creating neuronal relays, increased BBB } \\
\text { score and electrophysiology }\end{array}$ & Lu et al., 2012 \\
\hline $\begin{array}{l}\text { Rat bilateral CST } \\
\text { and right quadrant } \\
\text { lesions }\end{array}$ & Fibrin matrix (Category I) & $\begin{array}{l}\text { Rat E14 fetal spinal cells } \\
\text { with cocktail of growth } \\
\text { factors }\end{array}$ & $\begin{array}{l}\text { Neuronal differentiation and growth of NSPCs, } \\
\text { extensive CST growth into the matrix creating } \\
\text { neuronal relays, the staircase task with } \\
\text { increased level reached and pellets eaten }\end{array}$ & Kadoya et al., 2016 \\
\hline $\begin{array}{l}\text { Rat T2 clip } \\
\text { compression }\end{array}$ & $\begin{array}{l}\text { PDGF-A-conjugated HAMC } \\
\text { (modified Category III/IV) }\end{array}$ & $\begin{array}{l}\text { Adult rat SVZ-derived } \\
\text { NSPCs }\end{array}$ & $\begin{array}{l}\text { Enhanced sparing of host oligodendrocytes } \\
\text { and neurons, increased fine motor (horizontal } \\
\text { ladder) changes but not gross motor skills } \\
\text { (BBB) }\end{array}$ & Mothe et al., 2013 \\
\hline $\begin{array}{l}\text { Rat T9/T10 lateral } \\
\text { hemisection }\end{array}$ & $\begin{array}{l}4 \mathrm{~mm} \text { oriented porous PLGA } \\
\text { scaffold (Category II) }\end{array}$ & Murine NSCs (clone C17.2) & $\begin{array}{l}\text { Increased cell survival, tissue preservation, } \\
\text { increased NF axonal growth within lesion site, } \\
\text { increased sensorimotor cortex traced BDA } \\
\text { fibers rostral and caudal to graft coupled with } \\
\text { GAP-43, increased BBB }\end{array}$ & Teng et al., 2002 \\
\hline $\begin{array}{l}\text { Rat T8/T9 } \\
\text { transection }\end{array}$ & $\begin{array}{l}2 \mathrm{~mm} \text { PLGA scaffolds (with } 7 \\
\text { longitudinal channels, each with } \\
\text { a diameter of } 660 \mu \mathrm{m} \text { ) and } \\
\text { Matrigel (Category II) }\end{array}$ & $\begin{array}{l}\text { Rat E14.5 NSCs } \\
\text { (telencephalon/diencephalon) } \\
\text { or adult rat SCs }\end{array}$ & $\begin{array}{l}\text { Increased axonal fibers throughout scaffold but } \\
\text { no change in BBB score }\end{array}$ & Olson et al., 2009 \\
\hline $\begin{array}{l}\text { Rat T9-T10 lateral } \\
\text { hemisection }\end{array}$ & $\begin{array}{l}\text { Oriented PLGA scaffold with } \\
\text { macroporous 4-arm PEG } \\
\text { hydrogel coated with PLL } \\
\text { (Category II) }\end{array}$ & $\begin{array}{l}\text { Endothelial cells and NSPCs } \\
\text { (from the SVZ zone of P1 } \\
\text { GFP rats) }\end{array}$ & $\begin{array}{l}\text { Increase in functional blood vessels, } \\
\text { differentiation of NSPCs, increased NF staining } \\
\text { at host/graft interface and epicenter and } \\
\text { regenerating axons }\end{array}$ & Rauch et al., 2009 \\
\hline Rat T8 transection & $\begin{array}{l}10 \text { mm laminin-coated chitosan } \\
\text { channels (Category II) }\end{array}$ & $\begin{array}{l}\text { Adult rat brain or spinal } \\
\text { NSPCs }\end{array}$ & $\begin{array}{l}14 \text { week survival, differentiation (astrocytes and } \\
\text { oligodendrocytes), decreased cyst formation } \\
\text { and increased tissue bridge formation, no CST } \\
\text { growth into scaffold nor functional } \\
\text { improvement. }\end{array}$ & Nomura et al., 2008 \\
\hline $\begin{array}{l}\text { Rat T8 clip } \\
\text { compression }\end{array}$ & $\begin{array}{l}\text { Un-coated chitosan channels } \\
\text { (Category II) }\end{array}$ & Adult rat neurosphere NSPC & $\begin{array}{l}\text { 5-fold increase in cell survival but no tissue } \\
\text { bridging or functional change at } 9 \text { weeks }\end{array}$ & Bozkurt et al., 2010 \\
\hline $\begin{array}{l}\text { Rat T10 } \\
\text { transection }\end{array}$ & $\begin{array}{l}2 \text { mm oriented macroporous } \\
\text { PLGA scaffold (Category II) }\end{array}$ & $\begin{array}{l}\text { Rat P1-P3 hippocampal } \\
\text { NSC-NT-3/NSC-TrkC } \\
\text { (co-culture), naïve NSCs }\end{array}$ & $\begin{array}{l}\text { Differentiation into mature neurons with } \\
\text { synapse formation, preservation of neurons in } \\
\text { the sensorimotor cortex, red nucleus and } \\
\text { Clarke's nuclei, increased NF rostrocaudal and } \\
\text { epicenter staining, increased BBB score }\end{array}$ & Du et al., 2011 \\
\hline $\begin{array}{l}\text { Rat T10 } \\
\text { transection }\end{array}$ & $\begin{array}{l}2 \text { mm Gelfoam scaffolds } \\
\text { (Category II) }\end{array}$ & $\begin{array}{l}\text { Co-cultured NT-3-SC and } \\
\text { TrkC-NSC, naïve NSCs }\end{array}$ & $\begin{array}{l}\text { Increased BBB score, increased cortical } \\
\text { somatosensory evoked potentials and cortical } \\
\text { motor evoked potentials, increased neuronal } \\
\text { differentiation, increased cell survival of internal } \\
\text { pyramidal layer, red nuclei and Clarke's } \\
\text { nucleus, increased SC myelination and } \\
\text { synapse formation }\end{array}$ & Wang et al., 2011 \\
\hline $\begin{array}{l}\text { Rat lateral T7-T8 } \\
\text { hemisection }\end{array}$ & $\begin{array}{l}\text { NT-3 expression PCL scaffolds } \\
\text { (Category II) }\end{array}$ & $\begin{array}{l}\text { Human immortalized NSC } \\
\text { line (F3) + ChABCase }\end{array}$ & $\begin{array}{l}\text { Differentiation into neurons and } \\
\text { oligodendrocytes, white matter sparing, } \\
\text { regenerative markers (GAP- } 43 \text { and } \\
\text { synaptotagmin), increased BBB score and } \\
\text { MEP, decreased errors on the GridWalk }\end{array}$ & Hwang et al., 2011 \\
\hline $\begin{array}{l}\text { Rat T13-L2 lateral } \\
\text { hemisection }\end{array}$ & $\begin{array}{l}4 \mathrm{~mm} \text { porous collagen scaffold } \\
\text { conjugated with neutralizing } \\
\text { antibody of EGFR (Category II) }\end{array}$ & Neonatal NPCs & $\begin{array}{l}\text { Increased neuronal differentiation, increased in } \\
\text { BBB score and angle on inclined plane }\end{array}$ & Li et al., 2013 \\
\hline
\end{tabular}

reactions) that were non-existent previously, allowing for new multifaceted approaches. Given these advances it may be of importance to revisit many combinations that were presented here but not performed under ideal conditions. For example, cell survival on some scaffolds was poor, likely due to the degradation of the scaffold during the study. Such work can now be repeated with more stable scaffolds and with additional coating of the scaffold with extracellular matrix proteins to increase survival and attachement (Hou et al., 2005; Tian et al., 2005). In addition, experiments comparing the combination of a single biomaterial with various cell types in a given SCI model would be beneficial in contrasting the effectiveness of each combinatorial therapy. For 
example, PGLA scaffolds seeded with NSPCs or SCs (Category II) were compared to empty scaffolds in a $2 \mathrm{~mm}$ full transection T8-T9 model, clearly showing that cell-seeded scaffolds increased axonal regeneration over empty control scaffolds and while not significant SC-seeded scaffolds trended to greater axonal regrowth than NSPC-seeded scaffolds (Olson et al., 2009). The current use of transgenic lines provides easy visual tracking of grafted cells allowing for a better understanding of cell survival, cell migration, differentiation, tissue bridging, synaptic connections and neuronal relays forming. For future studies it is of great importance that relevant functional assays be performed in combination with histological work along with proper controls showing the observed improvement can be directly linked to the observed host-graft integration or axonal regeneration, for example through a re-transection or ablation study.

\section{PERSPECTIVES OF CELL-SEEDED BIOMATERIAL STRATEGIES}

The combination of cell transplantation and biomaterial scaffold implantation provides a promising tissue engineering strategy for SCI treatment that addresses the replacement of lost neural tissue and the support of axonal regeneration to achieve functional recovery. The poor survival rate of cells transplanted into the harsh post-SCI environment challenges their ability to fill and bridge the spinal lesion cavity or even provide physical and/or trophic support for axonal regrowth. In this context, biomaterial scaffolds provide a physical matrix for cell attachment, proliferation and differentiation that is protected from the harsh lesion microenvironment (Novikova et al., 2006; Führmann et al., 2017). In addition in such combinatorial approaches, the grafted cells aid scaffold integration into the host spinal environment by forming tissue bridges enticing axonal growth into and through the scaffold, recreating the lost neural tissue. While it is difficult to compare different SCI

\section{REFERENCES}

Abrams, M. B., Dominguez, C., Pernold, K., Regera, R., Wiesenfeld-Hallin, Z., Olson, L., et al. (2009). Multipotent mesenchymal stromal cells attenuate chronic inflammation and injury-induced sensitivity to mechanical stimuli in experimental spinal cord injury. Restor. Neurol. Neurosci. 27, 307-321. doi: 10.3233/RNN-2009-0480

Afshari, F. T., Kappagantula, S., and Fawcett, J. W. (2009). Extrinsic and intrinsic factors controlling axonal regeneration after spinal cord injury. Expert Rev. Mol. Med. 11:e37. doi: 10.1017/S1462399409 001288

Amr, S. M., Gouda, A., Koptan, W. T., Galal, A. A., Abdel-Fattah, D. S., Rashed, L. A., et al. (2014). Bridging defects in chronic spinal cord injury using peripheral nerve grafts combined with a chitosan- laminin scaffold and enhancing regeneration through them by co-transplantation with bone-marrow-derived mesenchymal stem cells: case series of 14 patients. J. Spinal Cord Med. 37, 54-71. doi: 10.1179/2045772312Y.0000 000069

Anderson, K. D., Guest, J. D., Dietrich, W. D., Bunge, M. B., Curiel, R., Dididze, M., et al. (2017). Safety of autologous human Schwann cell transplantation in subacute thoracic spinal cord injury. J. Neurotrauma 34, 2950-2963. doi: 10.1089/neu.2016.4895 lesion models and severities, species, cell types and biomaterial scaffolds used, many studies indicate that cell-seeded biomaterial scaffolds lead to greater axonal regrowth and sometimes better functional outcomes than biomaterial scaffolds alone (Wang et al., 1995, 2011, 2017; Teng et al., 2002; Joosten et al., 2004; Deumens et al., 2006a; Nomura et al., 2008; Olson et al., 2009; Rauch et al., 2009; Du et al., 2011; Hwang et al., 2011; Gao et al., 2013; Li et al., 2013; Zeng et al., 2015). Additionaly, from a few studies presented here there is a strong indication that biomaterial-supported cell transplantation is greater than cell transplantation alone (Teng et al., 2002; Rauch et al., 2009; Bozkurt et al., 2010), unfortunately this is not a direct comparison that is often performed. Biomaterial-supported cell transplantation reduces tissue loss, inflammation and reactive astrogliosis, increases tissue integrity and bridging of the lesion site which has led to increased axonal growth across the lesion as well as increased functional improvements. Combining various cell types and growth factors to increase tissue bridging and integration of the biomaterial along with increased support of axonal regeneration not only into the biomaterial but also re-entry and long distance growth into the host parenchyma would likely substanstially promote functional improvements. Taken together thus far the work in biomaterial-supported cell transplantation strongly encourages a path forward toward combinatorial treatment of SCI.

\section{AUTHOR CONTRIBUTIONS}

SL, TS, and RP: Researched, wrote, and edited the manuscript. NW: Edited the manuscript and provided expert feedback.

\section{FUNDING}

Supported by a grant from the Deutsche Forschungsgemeinschaft (BL414/3-1) (awarded to NW).

Anderson, M. A., Burda, J. E., Ren, Y., Ao, Y., O'shea, T. M., Kawaguchi, R., et al. (2016). Astrocyte scar formation aids central nervous system axon regeneration. Nature 532, 195-200. doi: 10.1038/nature17623

Antonic, A., Sena, E. S., Lees, J. S., Wills, T. E., Skeers, P., Batchelor, P. E., et al. (2013). Stem cell transplantation in traumatic spinal cord injury: a systematic review and meta-analysis of animal studies. PLoS Biol. 11:e1001738. doi: 10.1371/journal.pbio.1001738

Assinck, P., Duncan, G. J., Hilton, B. J., Plemel, J. R., and Tetzlaff, W. (2017). Cell transplantation therapy for spinal cord injury. Nat. Neurosci. 20, 637-647. doi: 10.1038/nn.4541

Assuncao-Silva, R. C., Gomes, E. D., Sousa, N., Silva, N. A., and Salgado, A. J. (2015). Hydrogels and cell based therapies in spinal cord injury regeneration. Stem Cells Int. 2015:948040. doi: 10.1155/2015/948040

Atala, A. (2000). Tissue engineering of artificial organs. J. Endourol. 14, 49-57. doi: $10.1089 /$ end.2000.14.49

Ayuso-Sacido, A., Moliterno, J. A., Kratovac, S., Kapoor, G. S., O'rourke, D. M., Holland, E. C., et al. (2010). Activated EGFR signaling increases proliferation, survival, and migration and blocks neuronal differentiation in post-natal neural stem cells. J. Neurooncol. 97, 323-337. doi: 10.1007/s11060-009-0035-x

Badner, A., Siddiqui, A. M., and Fehlings, M. G. (2017). Spinal cord injuries: how could cell therapy help? Expert Opin. Biol. Ther. 17, 529-541. doi: 10.1080/14712598.2017.1308481 
Baldwin, K. T., and Eroglu, C. (2017). Molecular mechanisms of astrocyte-induced synaptogenesis. Curr. Opin. Neurobiol. 45, 113-120. doi: 10.1016/j.conb.2017.05.006

Bartholomew, A., Sturgeon, C., Siatskas, M., Ferrer, K., McIntosh, K., Patil, S., et al. (2002). Mesenchymal stem cells suppress lymphocyte proliferation in vitro and prolong skin graft survival in vivo. Exp. Hematol. 30, 42-48. doi: 10.1016/S0301-472X(01)00769-X

Bellenchi, G. C., Volpicelli, F., Piscopo, V., Perrone-Capano, C., and Di Porzio, U. (2013). Adult neural stem cells: an endogenous tool to repair brain injury? J. Neurochem. 124, 159-167. doi: 10.1111/jnc.12084

Bernstein, J. J., and Goldberg, W. J. (1991). Grafted fetal astrocyte migration can prevent host neuronal atrophy: comparison of astrocytes from cultures and whole piece donors. Restor. Neurol. Neurosci. 2, 261-270.

Bidarra, S. J., Barrias, C. C., and Granja, P. L. (2014). Injectable alginate hydrogels for cell delivery in tissue engineering. Acta Biomater. 10, 1646-1662. doi: 10.1016/j.actbio.2013.12.006

Blesch, A., and Tuszynski, M. H. (2009). Spinal cord injury: plasticity, regeneration and the challenge of translational drug development. Trends Neurosci. 32, 41-47. doi: 10.1016/j.tins.2008.09.008

Boisserand, L. S., Kodama, T., Papassin, J., Auzely, R., Moisan, A., Rome, C., et al. (2016). Biomaterial applications in cell-based therapy in experimental stroke. Stem Cells Int. 2016:6810562. doi: 10.1155/2016/6810562

Bozkurt, G., Mothe, A. J., Zahir, T., Kim, H., Shoichet, M. S., and Tator, C. H. (2010). Chitosan channels containing spinal cord-derived stem/progenitor cells for repair of subacute spinal cord injury in the rat. Neurosurgery 67, 1733-1744. doi: 10.1227/NEU.0b013e3181f9af35

Brock, J. H., Graham, L., Staufenberg, E., Collyer, E., Koffler, J., and Tuszynski, M. H. (2016). Bone marrow stromal cell intraspinal transplants fail to improve motor outcomes in a severe model of spinal cord injury. J. Neurotrauma 33, 1103-1114. doi: 10.1089/neu.2015.4009

Cao, J., Sun, C., Zhao, H., Xiao, Z., Chen, B., Gao, J., et al. (2011). The use of laminin modified linear ordered collagen scaffolds loaded with laminin-binding ciliary neurotrophic factor for sciatic nerve regeneration in rats. Biomaterials 32, 3939-3948. doi: 10.1016/j.biomaterials.2011.02.020

Cao, Q. L., Howard, R. M., Dennison, J. B., and Whittemore, S. R. (2002). Differentiation of engrafted neuronal-restricted precursor cells is inhibited in the traumatically injured spinal cord. Exp. Neurol. 177, 349-359. doi: 10.1006/exnr.2002.7981

Carballo-Molina, O. A., and Velasco, I. (2015). Hydrogels as scaffolds and delivery systems to enhance axonal regeneration after injuries. Front. Cell. Neurosci. 9:13. doi: $10.3389 /$ fncel.2015.00013

Chen, B. K., Knight, A. M., De Ruiter, G. C. W., Spinner, R. J., Yaszemski, M. J., Currier, B. L., et al. (2009). Axon regeneration through scaffold into distal spinal cord after transection. J. Neurotrauma 26, 1759-1771. doi: 10.1089/neu.2008.0610

Chen, X. G., Katakowski, M., Li, Y., Lu, D. Y., Wang, L., Zhang, L. J., et al. (2002). Human bone marrow stromal cell cultures conditioned by traumatic brain tissue extracts: growth factor production. J. Neurosci. Res. 69, 687-691. doi: $10.1002 /$ jnr.10334

Chu, T., Zhou, H., Li, F., Wang, T., Lu, L., and Feng, S. (2014). Astrocyte transplantation for spinal cord injury: current status and perspective. Brain Res. Bull. 107, 18-30. doi: 10.1016/j.brainresbull.2014. 05.003

Cizkova, D., Rosocha, J., Vanicky, I., Jergova, S., and Cizek, M. (2006). Transplants of human mesenchymal stem cells improve functional recovery after spinal cord injury in the rat. Cell. Mol. Neurobiol. 26, 1167-1180. doi: 10.1007/s10571-006-9093-1

Corti, S., Locatelli, F., Donadoni, C., Strazzer, S., Salani, S., Del Bo, R., et al. (2002). Neuroectodermal and microglial differentiation of bone marrow cells in the mouse spinal cord and sensory ganglia. J. Neurosci. Res. 70, 721-733. doi: 10.1002/jnr.10455

Cregg, J. M., Depaul, M. A., Filous, A. R., Lang, B. T., Tran, A., and Silver, J. (2014). Functional regeneration beyond the glial scar. Exp. Neurol. 253, 197-207. doi: 10.1016/j.expneurol.2013.12.024

Danilov, C. A., and Steward, O. (2015). Conditional genetic deletion of PTEN after a spinal cord injury enhances regenerative growth of CST axons and motor function recovery in mice. Exp. Neurol. 266, 147-160. doi: 10.1016/j.expneurol.2015.02.012
Davies, J. E., Huang, C., Proschel, C., Noble, M., Mayer-Proschel, M., and Davies, S. J. (2006). Astrocytes derived from glial-restricted precursors promote spinal cord repair. J. Biol. 5:7. doi: 10.1186/jbiol35

Davies, J. E., Proschel, C., Zhang, N., Noble, M., Mayer-Proschel, M., and Davies, S. J. (2008). Transplanted astrocytes derived from BMP- or CNTF-treated glialrestricted precursors have opposite effects on recovery and allodynia after spinal cord injury. J. Biol. 7:24. doi: 10.1186/jbiol85

Davies, S. J., Shih, C. H., Noble, M., Mayer-Proschel, M., Davies, J. E., and Proschel, C. (2011). Transplantation of specific human astrocytes promotes functional recovery after spinal cord injury. PLoS ONE 6:e17328. doi: 10.1371/journal.pone.0017328

Deans, R. J., and Moseley, A. B. (2000). Mesenchymal stem cells: biology and potential clinical uses. Exp. Hematol. 28, 875-884. doi: 10.1016/S0301-472X(00)00482-3

Deng, L. X., Hu, J. G., Liu, N. K., Wang, X. F., Smith, G. M., Wen, X. J., et al. (2011). GDNF modifies reactive astrogliosis allowing robust axonal regeneration through Schwann cell-seeded guidance channels after spinal cord injury. Exp. Neurol. 229, 238-250. doi: 10.1016/j.expneurol.2011.02.001

Deumens, R., Koopmans, G. C., Honig, W. M., Hamers, F. P., Maquet, V., Jerome, R., et al. (2006a). Olfactory ensheathing cells, olfactory nerve fibroblasts and biomatrices to promote long-distance axon regrowth and functional recovery in the dorsally hemisected adult rat spinal cord. Exp. Neurol. 200, 89-103. doi: 10.1016/j.expneurol.2006.01.030

Deumens, R., Koopmans, G. C., Honig, W. M., Maquet, V., Jerome, R., Steinbusch, H. W., et al. (2006b). Limitations in transplantation of astroglia-biomatrix bridges to stimulate corticospinal axon regrowth across large spinal lesion gaps. Neurosci. Lett. 400, 208-212. doi: 10.1016/j.neulet.2006.02.050

Deumens, R., Van Gorp, S. F., Bozkurt, A., Beckmann, C., Fuhrmann, T., Montzka, K., et al. (2013). Motor outcome and allodynia are largely unaffected by novel olfactory ensheathing cell grafts to repair low-thoracic lesion gaps in the adult rat spinal cord. Behav. Brain Res. 237, 185-189. doi: 10.1016/j.bbr.2012.09.036

Devivo, M. J., Go, B. K., and Jackson, A. B. (2002). Overview of the national spinal cord injury statistical center database. J. Spinal Cord Med. 25, 335-338. doi: $10.1080 / 10790268.2002 .11753637$

Dey, I., Midha, N., Singh, G., Forsyth, A., Walsh, S. K., Singh, B., et al. (2013). Diabetic Schwann cells suffer from nerve growth factor and neurotrophin3 underproduction and poor associability with axons. Glia 61, 1990-1999. doi: $10.1002 /$ glia.22570

Du, B. L., Xiong, Y., Zeng, C. G., He, L. M., Zhang, W., Quan, D. P., et al. (2011). Transplantation of artificial neural construct partly improved spinal tissue repair and functional recovery in rats with spinal cord transection. Brain Res. 1400, 87-98. doi: 10.1016/j.brainres.2011.05.019

East, E., De Oliveira, D. B., Golding, J. P., and Phillips, J. B. (2010). Alignment of astrocytes increases neuronal growth in three-dimensional collagen gels and is maintained following plastic compression to form a spinal cord repair conduit. Tissue Eng. Part A 16, 3173-3184. doi: 10.1089/ten.tea.2010 .0017

Falnikar, A., Li, K., and Lepore, A. C. (2015). Therapeutically targeting astrocytes with stem and progenitor cell transplantation following traumatic spinal cord injury. Brain Res. 1619, 91-103. doi: 10.1016/j.brainres.2014.09.037

Fan, C., Zheng, Y., Cheng, X., Qi, X., Bu, P., Luo, X., et al. (2013). Transplantation of D15A-expressing glial-restricted-precursor-derived astrocytes improves anatomical and locomotor recovery after spinal cord injury. Int. J. Biol. Sci. 9, 78-93. doi: $10.7150 /$ ijbs.5626

Faulkner, J. R., Herrmann, J. E., Woo, M. J., Tansey, K. E., Doan, N. B., and Sofroniew, M. V. (2004). Reactive astrocytes protect tissue and preserve function after spinal cord injury. J. Neurosci. 24, 2143-2155. doi: 10.1523/JNEUROSCI.3547-03.2004

Feron, F., Perry, C., Cochrane, J., Licina, P., Nowitzke, A., Urquhart, S., et al. (2005). Autologous olfactory ensheathing cell transplantation in human spinal cord injury. Brain 128, 2951-2960. doi: 10.1093/brain/awh657

Filous, A. R., Miller, J. H., Coulson-Thomas, Y. M., Horn, K. P., Alilain, W. J., and Silver, J. (2010). Immature astrocytes promote CNS axonal regeneration when combined with chondroitinase ABC. Dev. Neurobiol. 70, 826-841. doi: $10.1002 /$ dneu. 20820

Fouad, K., Schnell, L., Bunge, M. B., Schwab, M. E., Liebscher, T., and Pearse, D. D. (2005). Combining Schwann cell bridges and olfactoryensheathing glia grafts with chondroitinase promotes locomotor recovery 
after complete transection of the spinal cord. J. Neurosci. 25, 1169-1178. doi: 10.1523/JNEUROSCI.3562-04.2005

Franssen, E. H., De Bree, F. M., and Verhaagen, J. (2007). Olfactory ensheathing glia: their contribution to primary olfactory nervous system regeneration and their regenerative potential following transplantation into the injured spinal cord. Brain Res. Rev. 56, 236-258. doi: 10.1016/j.brainresrev.2007.07.013

Franz, S., Weidner, N., and Blesch, A. (2012). Gene therapy approaches to enhancing plasticity and regeneration after spinal cord injury. Exp. Neurol. 235, 62-69. doi: 10.1016/j.expneurol.2011.01.015

Fu, W., Wang, S. J., Zhou, G. D., Liu, W., Cao, Y., and Zhang, W. J. (2012). Residual undifferentiated cells during differentiation of induced pluripotent stem cells in vitro and in vivo. Stem Cells Dev. 21, 521-529. doi: 10.1089/scd.2011.0131

Führmann, T., Anandakumaran, P. N., and Shoichet, M. S. (2017). Combinatorial therapies after spinal cord injury: how can biomaterials help? Adv. Healthc. Mater. 6:1601130. doi: 10.1002/adhm.201601130

Führmann, T., Tam, R. Y., Ballarin, B., Coles, B., Elliott Donaghue, I., Van Der Kooy, D., et al. (2016). Injectable hydrogel promotes early survival of induced pluripotent stem cell-derived oligodendrocytes and attenuates longterm teratoma formation in a spinal cord injury model. Biomaterials 83, 23-36. doi: 10.1016/j.biomaterials.2015.12.032

Gao, M. Y., Lu, P., Bednark, B., Lynam, D., Conner, J. M., Sakamoto, J., et al. (2013). Templated agarose scaffolds for the support of motor axon regeneration into sites of complete spinal cord transection. Biomaterials 34, 1529-1536. doi: 10.1016/j.biomaterials.2012.10.070

Geller, H. M., and Fawcett, J. W. (2002). Building a bridge: engineering spinal cord repair. Exp. Neurol. 174, 125-136. doi: 10.1006/exnr.2002.7865

Ghirnikar, R. S., and Eng, L. F. (1994). Astrocyte-Schwann cell interactions in culture. Glia 11, 367-377. doi: 10.1002/glia.440110409

Godinho, M. J., Teh, L., Pollett, M. A., Goodman, D., Hodgetts, S. I., Sweetman, I., et al. (2013). Immunohistochemical, ultrastructural and functional analysis of axonal regeneration through peripheral nerve grafts containing Schwann cells expressing BDNF, CNTF or NT3. PLoS ONE 8:e69987. doi: 10.1371/journal.pone.0069987

Gomes-Osman, J., Cortes, M., Guest, J., and Pascual-Leone, A. (2016). A systematic review of experimental strategies aimed at improving motor function after acute and chronic spinal cord injury. J. Neurotrauma 33, 425-438. doi: 10.1089/neu.2014.3812

Gong, Y., Wang, H. F., and Xia, H. J. (2015). Stable transfection into rat bone marrow mesenchymal stem cells by lentivirus-mediated NT-3. Mol. Med. Rep. 11,367-373. doi: 10.3892/mmr.2014.2727

Granger, N., Franklin, R. J., and Jeffery, N. D. (2014). Cell therapy for spinal cord injuries: what is really going on? Neuroscientist 20, 623-638. doi: $10.1177 / 1073858413514635$

Gros, T., Sakamoto, J. S., Blesch, A., Havton, L. A., and Tuszynski, M. H. (2010). Regeneration of long-tract axons through sites of spinal cord injury using templated agarose scaffolds. Biomaterials 31, 6719-6729. doi: $10.1016 /$ j.biomaterials.2010.04.035

Grulova, I., Slovinska, L., Blasko, J., Devaux, S., Wisztorski, M., Salzet, M., et al. (2015). Delivery of alginate scaffold releasing two trophic factors for spinal cord injury repair. Sci. Rep. 5:13702. doi: 10.1038/srep 13702

Gunther, M. I., Gunther, M., Schneiders, M., Rupp, R., and Blesch, A. (2015a). AngleJ: a new tool for the automated measurement of neurite growth orientation in tissue sections. J. Neurosci. Methods 251, 143-150. doi: 10.1016/j.jneumeth.2015.05.021

Gunther, M. I., Weidner, N., Muller, R., and Blesch, A. (2015b). Cellseeded alginate hydrogel scaffolds promote directed linear axonal regeneration in the injured rat spinal cord. Acta Biomater. 27, 140-150. doi: 10.1016/j.actbio.2015.09.001

Guo, X., Dillman, J. F. III., Dawson, V. L., and Dawson, T. M. (2001). Neuroimmunophilins: novel neuroprotective and neuroregenerative targets. Ann. Neurol. 50, 6-16. doi: 10.1002/ana.1030

Haas, C., and Fischer, I. (2013). Human astrocytes derived from glial restricted progenitors support regeneration of the injured spinal cord. J. Neurotrauma 30, 1035-1052. doi: 10.1089/neu.2013.2915

Haas, C., Neuhuber, B., Yamagami, T., Rao, M., and Fischer, I. (2012). Phenotypic analysis of astrocytes derived from glial restricted precursors and their impact on axon regeneration. Exp. Neurol. 233, 717-732. doi: 10.1016/j.expneurol.2011.11.002
Hara, M., Kobayakawa, K., Ohkawa, Y., Kumamaru, H., Yokota, K., Saito, T., et al. (2017). Interaction of reactive astrocytes with type I collagen induces astrocytic scar formation through the integrin-N-cadherin pathway after spinal cord injury. Nat. Med. 23, 818-828. doi: 10.1038/nm.4354

Hatami, M., Mehrjardi, N. Z., Kiani, S., Hemmesi, K., Azizi, H., Shahverdi, A., et al. (2009). Human embryonic stem cell-derived neural precursor transplants in collagen scaffolds promote recovery in injured rat spinal cord. Cytotherapy 11, 618-630. doi: 10.1080/14653240903005802

Hellal, F., Hurtado, A., Ruschel, J., Flynn, K. C., Laskowski, C. J., Umlauf, M., et al. (2011). Microtubule stabilization reduces scarring and causes axon regeneration after spinal cord injury. Science 331, 928-931. doi: $10.1126 /$ science. 1201148

Hill, C. E., Proschel, C., Noble, M., Mayer-Proschel, M., Gensel, J. C., Beattie, M. S., et al. (2004). Acute transplantation of glial-restricted precursor cells into spinal cord contusion injuries: survival, differentiation, and effects on lesion environment and axonal regeneration. Exp. Neurol. 190, 289-310. doi: 10.1016/j.expneurol.2004.05.043

Hofstetter, C. P., Holmstrom, N. A., Lilja, J. A., Schweinhardt, P., Hao, J., Spenger, C., et al. (2005). Allodynia limits the usefulness of intraspinal neural stem cell grafts; directed differentiation improves outcome. Nat. Neurosci. 8, 346-353. doi: $10.1038 / \mathrm{nn} 1405$

Hou, S., Xu, Q., Tian, W., Cui, F., Cai, Q., Ma, J., et al. (2005). The repair of brain lesion by implantation of hyaluronic acid hydrogels modified with laminin. J. Neurosci. Methods 148, 60-70. doi: 10.1016/j.jneumeth.2005.04.016

Hu, B. Y., Weick, J. P., Yu, J., Ma, L. X., Zhang, X. Q., Thomson, J. A., et al. (2010). Neural differentiation of human induced pluripotent stem cells follows developmental principles but with variable potency. Proc. Natl. Acad. Sci. U.S.A. 107, 4335-4340. doi: 10.1073/pnas.0910012107

Hurtado, A., Moon, L. D. F., Maquet, V., Blits, B., Jerome, R., and Oudega, M. (2006). Poly (D,L-lactic acid) macroporous guidance scaffolds seeded with Schwann cells genetically modified to secrete a bi-functional neurotrophin implanted in the completely transected adult rat thoracic spinal cord. Biomaterials 27, 430-442. doi: 10.1016/j.biomaterials.2005.07.014

Hwang, D. H., Kim, H. M., Kang, Y. M., Joo, I. S., Cho, C. S., Yoon, B. W., et al. (2011). Combination of multifaceted strategies to maximize the therapeutic benefits of neural stem cell transplantation for spinal cord repair. Cell Transplant. 20, 1361-1379. doi: 10.3727/096368910X557155

Iannotti, C., Ping Zhang, Y., Shields, C. B., Han, Y., Burke, D. A., and Xu, X. M. (2004). A neuroprotective role of glial cell line-derived neurotrophic factor following moderate spinal cord contusion injury. Exp. Neurol. 189, 317-332. doi: 10.1016/j.expneurol.2004.05.033

Iwanami, A., Kaneko, S., Nakamura, M., Kanemura, Y., Mori, H., Kobayashi, S., et al. (2005). Transplantation of human neural stem cells for spinal cord injury in primates. J. Neurosci. Res. 80, 182-190. doi: 10.1002/jnr.20436

Jain, N. B., Ayers, G. D., Peterson, E. N., Harris, M. B., Morse, L., O'connor, K. C., et al. (2015). Traumatic spinal cord injury in the United States, 1993-2012. J. Am. Med. Assoc. 313, 2236-2243. doi: 10.1001/jama.2015.6250

Jazayeri, S. B., Beygi, S., Shokraneh, F., Hagen, E. M., and Rahimi-Movaghar, V. (2015). Incidence of traumatic spinal cord injury worldwide: a systematic review. Eur. Spine J. 24, 905-918. doi: 10.1007/s00586-014-3424-6

Jin, Y., Neuhuber, B., Singh, A., Bouyer, J., Lepore, A., Bonner, J., et al. (2011). Transplantation of human glial restricted progenitors and derived astrocytes into a contusion model of spinal cord injury. J. Neurotrauma 28, 579-594. doi: 10.1089/neu.2010.1626

Joosten, E. A., Veldhuis, W. B., and Hamers, F. P. (2004). Collagen containing neonatal astrocytes stimulates regrowth of injured fibers and promotes modest locomotor recovery after spinal cord injury. J. Neurosci. Res. 77, 127-142. doi: $10.1002 / j n r .20088$

Kadoya, K., Lu, P., Nguyen, K., Lee-Kubli, C., Kumamaru, H., Yao, L., et al. (2016). Spinal cord reconstitution with homologous neural grafts enables robust corticospinal regeneration. Nat. Med. 22, 479-487. doi: 10.1038/nm .4066

Kanno, H., Pearse, D. D., Ozawa, H., Itoi, E., and Bunge, M. B. (2015). Schwann cell transplantation for spinal cord injury repair: its significant therapeutic potential and prospectus. Rev. Neurosci. 26, 121-128. doi: 10.1515/revneuro-2014-0068

Kanno, H., Pressman, Y., Moody, A., Berg, R., Muir, E. M., Rogers, J. H., et al. (2014). Combination of engineered Schwann cell grafts to secrete neurotrophin and chondroitinase promotes axonal regeneration 
and locomotion after spinal cord injury. J. Neurosci. 34, 1838-1855. doi: 10.1523/JNEUROSCI.2661-13.2014

Karamouzian, S., Nematollahi-Mahani, S. N., Nakhaee, N., and Eskandary, H. (2012). Clinical safety and primary efficacy of bone marrow mesenchymal cell transplantation in subacute spinal cord injured patients. Clin. Neurol. Neurosurg. 114, 935-939. doi: 10.1016/j.clineuro.2012.02.003

Khaing, Z. Z., Milman, B. D., Vanscoy, J. E., Seidlits, S. K., Grill, R. J., and Schmidt, C. E. (2011). High molecular weight hyaluronic acid limits astrocyte activation and scar formation after spinal cord injury. J. Neural Eng. 8:046033. doi: $10.1088 / 1741-2560 / 8 / 4 / 046033$

Khakh, B. S., and Sofroniew, M. V. (2015). Diversity of astrocyte functions and phenotypes in neural circuits. Nat. Neurosci. 18, 942-952. doi: 10.1038/nn.4043

Kim, B. G., Kang, Y. M., Phi, J. H., Kim, Y. H., Hwang, D. H., Choi, J. Y., et al. (2010). Implantation of polymer scaffolds seeded with neural stem cells in a canine spinal cord injury model. Cytotherapy 12, 841-845. doi: 10.3109/14653249.2010.501784

Kim, J. W., Ha, K. Y., Molon, J. N., and Kim, Y. H. (2013). Bone marrowderived mesenchymal stem cell transplantation for chronic spinal cord injury in rats comparative study between intralesional and intravenous transplantation. Spine 38, E1065-E1074. doi: 10.1097/BRS.0b013e31829839fa

Kim, M., Park, S. R., and Choi, B. H. (2014). Biomaterial scaffolds used for the regeneration of spinal cord injury (SCI). Histol. Histopathol. 29, 1395-1408. doi: 10.14670/HH-29.1395

Kimelberg, H. K., and Nedergaard, M. (2010). Functions of astrocytes and their potential as therapeutic targets. Neurotherapeutics 7, 338-353. doi: 10.1016/j.nurt.2010.07.006

Kliot, M., Smith, G. M., Siegal, J. D., and Silver, J. (1990). Astrocyte-polymer implants promote regeneration of dorsal root fibers into the adult mammalian spinal cord. Exp. Neurol. 109, 57-69. doi: 10.1016/S0014-4886(05)80008-1

Koprivica, V., Cho, K. S., Park, J. B., Yiu, G., Atwal, J., Gore, B., et al. (2005). EGFR activation mediates inhibition of axon regeneration by myelin and chondroitin sulfate proteoglycans. Science 310, 106-110. doi: 10.1126/science.1115462

Krishna, V., Konakondla, S., Nicholas, J., Varma, A., Kindy, M., and Wen, X. (2013). Biomaterial-based interventions for neuronal regeneration and functional recovery in rodent model of spinal cord injury: a systematic review. J. Spinal Cord Med. 36, 174-190. doi: 10.1179/2045772313Y.00000 00095

Kumar, A. A., Kumar, S. R., Narayanan, R., Arul, K., and Baskaran, M. (2009). Autologous bone marrow derived mononuclear cell therapy for spinal cord injury: a phase I/II clinical safety and primary efficacy data. Exp. Clin. Transplant. 7, 241-248.

Lakatos, A., Franklin, R. J. M., and Barnett, S. C. (2000). Olfactory ensheathing cells and Schwann cells differ in their in vitro interactions with astrocytes. Glia 32, 214-225. doi: 10.1002/1098-1136(200012)32:3<214::AID-GLIA20>3.0.CO;2-7

Lee, B. B., Cripps, R. A., Fitzharris, M., and Wing, P. C. (2014). The global map for traumatic spinal cord injury epidemiology: update 2011, global incidence rate. Spinal Cord 52, 110-116. doi: 10.1038/sc.2012.158

Lepore, A. C., Han, S. S., Tyler-Polsz, C. J., Cai, J., Rao, M. S., and Fischer, I. (2004). Differential fate of multipotent and lineage-restricted neural precursors following transplantation into the adult CNS. Neuron Glia Biol. 1, 113-126. doi: $10.1017 / S 1740925 \mathrm{X} 04000213$

Li, B. C., Jiao, S. S., Xu, C., You, H., and Chen, J. M. (2010). PLGA conduit seeded with olfactory ensheathing cells for bridging sciatic nerve defect of rats. J. Biomed. Mater. Res. A 94, 769-780. doi: 10.1002/jbm.a.32727

Li, X., Xiao, Z., Han, J., Chen, L., Xiao, H., Ma, F., et al. (2013). Promotion of neuronal differentiation of neural progenitor cells by using EGFR antibody functionalized collagen scaffolds for spinal cord injury repair. Biomaterials 34, 5107-5116. doi: 10.1016/j.biomaterials.2013.03.062

Li, Y., Field, P. M., and Raisman, G. (1997). Repair of adult rat corticospinal tract by transplants of olfactory ensheathing cells. Science 277, 2000-2002. doi: $10.1126 /$ science. 277.5334 .2000

Li, Y., Li, D., and Raisman, G. (2005). Interaction of olfactory ensheathing cells with astrocytes may be the key to repair of tract injuries in the spinal cord: the "pathway hypothesis". J. Neurocytol. 34, 343-351. doi: 10.1007/s11068-005-8361-1

Li, Z. W., Tang, R. H., Zhang, J. P., Tang, Z. P., Qu, W. S., Zhu, W. H., et al. (2011). Inhibiting epidermal growth factor receptor attenuates reactive astrogliosis and improves functional outcome after spinal cord injury in rats. Neurochem. Int 58, 812-819. doi: 10.1016/j.neuint.2011.03.007

Liddelow, S. A., and Barres, B. A. (2017). Reactive astrocytes: production, function, and therapeutic potential. Immunity 46, 957-967. doi: 10.1016/j.immuni.2017.06.006

Lin, X. Y., Lai, B. Q., Zeng, X., Che, M. T., Ling, E. A., Wu, W., et al. (2016). Cell transplantation and neuroengineering approach for spinal cord injury treatment: a summary of current laboratory findings and review of literature. Cell Transplant. 25, 1425-1438. doi: 10.3727/096368916X690836

Liu, S., Sandner, B., Schackel, T., Nicholson, L., Chtarto, A., Tenenbaum, L., et al. (2017). Regulated viral BDNF delivery in combination with Schwann cells promotes axonal regeneration through capillary alginate hydrogels after spinal cord injury. Acta Biomater. 60, 167-180. doi: 10.1016/j.actbio.2017.07.024

Liu, Z., Tang, Y., Lu, S., Zhou, J., Du, Z., Duan, C., et al. (2013). The tumourigenicity of iPS cells and their differentiated derivates. J. Cell. Mol. Med. 17, 782-791. doi: $10.1111 /$ jcmm. 12062

Lu, P., Blesch, A., and Tuszynski, M. H. (2004). Induction of bone marrow stromal cells to neurons: differentiation, transdifferentiation, or artifact? J. Neurosci. Res. 77, 174-191. doi: 10.1002/jnr.20148

Lu, P., Graham, L., Wang, Y., Wu, D., and Tuszynski, M. (2014a). Promotion of survival and differentiation of neural stem cells with fibrin and growth factor cocktails after severe spinal cord injury. J. Vis. Exp. e50641. doi: 10.3791/ 50641

Lu, P., Wang, Y., Graham, L., McHale, K., Gao, M., Wu, D., et al. (2012). Longdistance growth and connectivity of neural stem cells after severe spinal cord injury. Cell 150, 1264-1273. doi: 10.1016/j.cell.2012.08.020

Lu, P., Woodruff, G., Wang, Y., Graham, L., Hunt, M., Wu, D., et al. (2014b). Longdistance axonal growth from human induced pluripotent stem cells after spinal cord injury. Neuron 83, 789-796. doi: 10.1016/j.neuron.2014.07.014

Lukovic, D., Stojkovic, M., Moreno-Manzano, V., Jendelova, P., Sykova, E., Bhattacharya, S. S., et al. (2015). Concise review: reactive astrocytes and stem cells in spinal cord injury: good guys or bad guys? Stem Cells 33, 1036-1041. doi: 10.1002/stem.1959

Luo, Z., Yang, Y., Deng, Y., Sun, Y., Yang, H., and Wei, S. (2016). Peptideincorporated 3D porous alginate scaffolds with enhanced osteogenesis for bone tissue engineering. Colloids Surf. B Biointerfaces 143, 243-251. doi: 10.1016/j.colsurfb.2016.03.047

Macias, M. Y., Syring, M. B., Pizzi, M. A., Crowe, M. J., Alexanian, A. R., and Kurpad, S. N. (2006). Pain with no gain: allodynia following neural stem cell transplantation in spinal cord injury. Exp. Neurol. 201, 335-348. doi: 10.1016/j.expneurol.2006.04.035

Mackay-Sim, A., Feron, F., Cochrane, J., Bassingthwaighte, L., Bayliss, C., Davies, W., et al. (2008). Autologous olfactory ensheathing cell transplantation in human paraplegia: a 3-year clinical trial. Brain 131, 2376-2386. doi: 10.1093/brain/awn173

Madigan, N. N., McMahon, S., O'brien, T., Yaszemski, M. J., and Windebank, A. J. (2009). Current tissue engineering and novel therapeutic approaches to axonal regeneration following spinal cord injury using polymer scaffolds. Respir. Physiol. Neurobiol. 169, 183-199. doi: 10.1016/j.resp.2009.08.015

Marcol, W., Slusarczyk, W., Larysz-Brysz, M., Francuz, T., Jedrzejowska-Szypulka, H., Labuzek, K., et al. (2015). Grafted activated Schwann cells support survival of injured rat spinal cord white matter. World Neurosurg. 84, 511-519. doi: 10.1016/j.wneu.2015.04.027

Matsuda, R., Yoshikawa, M., Kimura, H., Ouji, Y., Nakase, H., Nishimura, F., et al. (2009). Cotransplantation of mouse embryonic stem cells and bone marrow stromal cells following spinal cord injury suppresses tumor development. Cell Transplant. 18, 39-54. doi: 10.3727/096368909788237122

Matsui, T., Akamatsu, W., Nakamura, M., and Okano, H. (2014). Regeneration of the damaged central nervous system through reprogramming technology: basic concepts and potential application for cell replacement therapy. Exp. Neurol. 260, 12-18. doi: 10.1016/j.expneurol.2012.09.016

McCall, J., Weidner, N., and Blesch, A. (2012). Neurotrophic factors in combinatorial approaches for spinal cord regeneration. Cell Tissue Res. 349, 27-37. doi: 10.1007/s00441-012-1388-6

McCreedy, D. A., Wilems, T. S., Xu, H., Butts, J. C., Brown, C. R., Smith, A. W., et al. (2014). Survival, differentiation, and migration of high-purity mouse embryonic stem cell-derived progenitor motor neurons in fibrin 
scaffolds after sub-acute spinal cord injury. Biomater. Sci. 2, 1672-1682. doi: 10.1039/C4BM00106K

Mekhail, M., Almazan, G., and Tabrizian, M. (2015). Purine-crosslinked injectable chitosan sponges promote oligodendrocyte progenitor cells' attachment and differentiation. Biomater. Sci. 3, 279-287. doi: 10.1039/C4BM00215F

Mendonca, M. V. P., Larocca, T. F., Souza, B. S. D., Villarreal, C. F., Silva, L. F. M., Matos, A. C., et al. (2014). Safety and neurological assessments after autologous transplantation of bone marrow mesenchymal stem cells in subjects with chronic spinal cord injury. Stem Cell Res. Ther. 5:126. doi: 10.1186/scrt516

Mertens, J., Marchetto, M. C., Bardy, C., and Gage, F. H. (2016). Evaluating cell reprogramming, differentiation and conversion technologies in neuroscience. Nat. Rev. Neurosci. 17, 424-437. doi: 10.1038/nrn.2016.46

Miller, C., Shanks, H., Witt, A., Rutkowski, G., and Mallapragada, S. (2001). Oriented Schwann cell growth on micropatterned biodegradable polymer substrates. Biomaterials 22, 1263-1269. doi: 10.1016/S0142-9612(00)00278-7

Mothe, A. J., Tam, R. Y., Zahir, T., Tator, C. H., and Shoichet, M. S. (2013). Repair of the injured spinal cord by transplantation of neural stem cells in a hyaluronan-based hydrogel. Biomaterials 34, 3775-3783. doi: 10.1016/j.biomaterials.2013.02.002

Noh, M. Y., Lim, S. M., Oh, K. W., Cho, K. A., Park, J., Kim, K. S., et al. (2016). Mesenchymal stem cells modulate the functional properties of microglia via TGF-beta secretion. Stem Cells Transl. Med. 5, 1538-1549. doi: 10.5966/sctm. 2015-0217

Nomura, H., Zahir, T., Kim, H., Katayama, Y., Kulbatski, I., Morshead, C. M., et al. (2008). Extramedullary chitosan channels promote survival of transplanted neural stem and progenitor cells and create a tissue bridge after complete spinal cord transection. Tissue Eng. Part A 14, 649-665. doi: 10.1089/tea.2007.0180

Novikova, L. N., Lobov, S., Wiberg, M., and Novikov, L. N. (2011). Efficacy of olfactory ensheathing cells to support regeneration after spinal cord injury is influenced by method of culture preparation. Exp. Neurol. 229, 132-142. doi: 10.1016/j.expneurol.2010.09.021

Novikova, L. N., Mosahebi, A., Wiberg, M., Terenghi, G., Kellerth, J. O., and Novikov, L. N. (2006). Alginate hydrogel and matrigel as potential cell carriers for neurotransplantation. J. Biomed. Mater. Res. A 77, 242-252. doi: 10.1002/jbm.a.30603

Novikova, L. N., Pettersson, J., Brohlin, M., Wiberg, M., and Novikov, L. N. (2008). Biodegradable poly-beta-hydroxybutyrate scaffold seeded with Schwann cells to promote spinal cord repair. Biomaterials 29, 1198-1206. doi: 10.1016/j.biomaterials.2007.11.033

Ogle, B. M., Bursac, N., Domian, I., Huang, N. F., Menasche, P., Murry, C. E., et al. (2016). Distilling complexity to advance cardiac tissue engineering. Sci. Transl. Med. 8:342ps313. doi: 10.1126/scitranslmed.aad2304

Ohta, M., Suzuki, Y., Noda, T., Ejiri, Y., Dezawa, M., Kataoka, K., et al. (2004). Bone marrow stromal cells infused into the cerebrospinal fluid promote functional recovery of the injured rat spinal cord with reduced cavity formation. Exp. Neurol. 187, 266-278. doi: 10.1016/j.expneurol.2004.01.021

Oliveri, R. S., Bello, S., and Biering-Sorensen, F. (2014). Mesenchymal stem cells improve locomotor recovery in traumatic spinal cord injury: systematic review with meta-analyses of rat models. Neurobiol. Dis. 62, 338-353. doi: 10.1016/j.nbd.2013.10.014

Olson, H. E., Rooney, G. E., Gross, L., Nesbitt, J. J., Galvin, K. E., Knight, A., et al. (2009). Neural stem cell- and Schwann cell-loaded biodegradable polymer scaffolds support axonal regeneration in the transected spinal cord. Tissue Eng. Part A 15, 1797-1805. doi: 10.1089/ten.tea.2008.0364

Onuma-Ukegawa, M., Bhatt, K., Hirai, T., Kaburagi, H., Sotome, S., Wakabayashi, Y., et al. (2015). Bone marrow stromal cells combined with a honeycomb collagen sponge facilitate neurite elongation in vitro and neural restoration in the hemisected rat spinal cord. Cell Transplant. 24, 1283-1297. doi: 10.3727/096368914X682134

Oraee-Yazdani, S., Hafizi, M., Atashi, A., Ashrafi, F., Seddighi, A. S., Hashemi, S. M., et al. (2016). Co-transplantation of autologous bone marrow mesenchymal stem cells and Schwann cells through cerebral spinal fluid for the treatment of patients with chronic spinal cord injury: safety and possible outcome. Spinal Cord 54, 102-109. doi: 10.1038/sc.2015.142

Park, H. C., Shim, Y. S., Ha, Y., Yoon, S. H., Park, S. R., Choi, B. H., et al. (2005). Treatment of complete spinal cord injury patients by autologous bone marrow cell transplantation and administration of granulocyte-macrophage colony stimulating factor. Tissue Eng. 11, 913-922. doi: 10.1089/ten.2005. 11.913

Park, S. S., Lee, Y. J., Lee, S. H., Lee, D., Choi, K., Kim, W. H., et al. (2012). Functional recovery after spinal cord injury in dogs treated with a combination of Matrigel and neural-induced adipose-derived mesenchymal Stem cells. Cytotherapy 14, 584-597. doi: 10.3109/14653249.2012.658913

Parr, A. M., Kulbatski, I., Zahir, T., Wang, X., Yue, C., Keating, A., et al. (2008). Transplanted adult spinal cord-derived neural stem/progenitor cells promote early functional recovery after rat spinal cord injury. Neuroscience 155 , 760-770. doi: 10.1016/j.neuroscience.2008.05.042

Pawar, K., Cummings, B. J., Thomas, A., Shea, L. D., Levine, A., Pfaff, S., et al. (2015a). Biomaterial bridges enable regeneration and re-entry of corticospinal tract axons into the caudal spinal cord after SCI: association with recovery of forelimb function. Biomaterials 65, 1-12. doi: 10.1016/j.biomaterials.2015.05.032

Pawar, K., Prang, P., Muller, R., Caioni, M., Bogdahn, U., Kunz, W., et al. (2015b). Intrinsic and extrinsic determinants of central nervous system axon outgrowth into alginate-based anisotropic hydrogels. Acta Biomater. 27, 131-139. doi: 10.1016/j.actbio.2015.08.032

Pearse, D. D., and Barakat, D. J. (2006). Cellular repair strategies for spinal cord injury. Expert Opin. Biol. Ther. 6, 639-652. doi: 10.1517/14712598.6.7.639

Pearse, D. D., Sanchez, A. R., Pereira, F. C., Andrade, C. M., Puzis, R., Pressman, Y., et al. (2007). Transplantation of Schwann cells and/or olfactory ensheathing glia into the contused spinal cord: survival, migration, axon association, and functional recovery. Glia 55, 976-1000. doi: 10.1002/glia.20490

Pencalet, P., Serguera, C., Corti, O., Privat, A., Mallet, J., and Gimenez Y Ribotta, M. (2006). Integration of genetically modified adult astrocytes into the lesioned rat spinal cord. J. Neurosci. Res. 83, 61-67. doi: 10.1002/jnr.20697

Plant, G. W., Bates, M. L., and Bunge, M. B. (2001). Inhibitory proteoglycan immunoreactivity is higher at the caudal than the rostral Schwann cell graft-transected spinal cord interface. Mol. Cell. Neurosci. 17, 471-487. doi: $10.1006 /$ mcne.2000.0948

Powell, E. M., and Geller, H. M. (1999). Dissection of astrocyte-mediated cues in neuronal guidance and process extension. Glia 26, 73-83.

Pritchard, C. D., Slotkin, J. R., Yu, D., Dai, H., Lawrence, M. S., Bronson, R. T., et al. (2010). Establishing a model spinal cord injury in the African green monkey for the preclinical evaluation of biodegradable polymer scaffolds seeded with human neural stem cells. J. Neurosci. Methods 188, 258-269. doi: 10.1016/j.jneumeth.2010.02.019

Qu, W. S., Tian, D. S., Guo, Z. B., Fang, J., Zhang, Q., Yu, Z. Y., et al. (2012). Inhibition of EGFR/MAPK signaling reduces microglial inflammatory response and the associated secondary damage in rats after spinal cord injury. J. Neuroinflammation 9:178. doi: 10.1186/1742-2094-9-178

Ramon-Cueto, A., and Nieto-Sampedro, M. (1992). Glial cells from adult rat olfactory bulb: immunocytochemical properties of pure cultures of ensheathing cells. Neuroscience 47, 213-220. doi: 10.1016/0306-4522(92)90134-N

Ramon-Cueto, A., Plant, G. W., Avila, J., and Bunge, M. B. (1998). Long-distance axonal regeneration in the transected adult rat spinal cord is promoted by olfactory ensheathing glia transplants. J. Neurosci. 18, 3803-3815.

Rath, E. M., Kelly, D., Bouldin, T. W., and Popko, B. (1995). Impaired peripheral nerve regeneration in a mutant strain of mice (Enr) with a Schwann cell defect. J. Neurosci. 15, 7226-7237.

Rauch, M. F., Hynes, S. R., Bertram, J., Redmond, A., Robinson, R., Williams, C., et al. (2009). Engineering angiogenesis following spinal cord injury: a coculture of neural progenitor and endothelial cells in a degradable polymer implant leads to an increase in vessel density and formation of the blood-spinal cord barrier. Eur. J. Neurosci. 29, 132-145. doi: 10.1111/j.1460-9568.2008.06567.x

Reeves, A., and Keirstead, H. S. (2012). Stem cell based strategies for spinal cord injury repair. Adv. Exp. Med. Biol. 760, 16-24. doi: 10.1007/978-1-4614-4090-1_2

Ritfeld, G. J., Patel, A., Chou, A., Novosat, T. L., Castillo, D. G., Roos, R., et al. (2015). The role of brain-derived neurotrophic factor in bone marrow stromal cell-mediated spinal cord repair. Cell Transplant. 24, 2209-2220. doi: 10.3727/096368915X686201

Rizek, P. N., and Kawaja, M. D. (2006). Cultures of rat olfactory ensheathing cells are contaminated with Schwann cells. Neuroreport 17, 459-462. doi: 10.1097/01.wnr.0000209000.32857.1b 
Robinson, J., and Lu, P. (2017). Optimization of trophic support for neural stem cell grafts in sites of spinal cord injury. Exp. Neurol. 291, 87-97. doi: 10.1016/j.expneurol.2017.02.007

Ruff, C. A., Wilcox, J. T., and Fehlings, M. G. (2012). Cell-based transplantation strategies to promote plasticity following spinal cord injury. Exp. Neurol. 235, 78-90. doi: 10.1016/j.expneurol.2011.02.010

Sandner, B., Rivera, F. J., Caioni, M., Nicholson, L., Eckstein, V., Bogdahn, U., et al. (2013). Bone morphogenetic proteins prevent bone marrow stromal cell-mediated oligodendroglial differentiation of transplanted adult neural progenitor cells in the injured spinal cord. Stem Cell Res. 11, 758-771. doi: 10.1016/j.scr.2013.05.003

Sasaki, M., Hains, B. C., Lankford, K. L., Waxman, S. G., and Kocsis, J. D. (2006). Protection of corticospinal tract neurons after dorsal spinal cord transection and engraftment of olfactory ensheathing cells. Glia 53, 352-359. doi: $10.1002 /$ glia.20285

Seyedhassantehrani, N., Li, Y., and Yao, L. (2016). Dynamic behaviors of astrocytes in chemically modified fibrin and collagen hydrogels. Integr. Biol. 8, 624-634. doi: 10.1039/C6IB00003G

Shin, J. C., Kim, K. N., Yoo, J., Kim, I. S., Yun, S., Lee, H., et al. (2015). Clinical trial of human fetal brain-derived neural stem/progenitor cell transplantation in patients with traumatic cervical spinal cord injury. Neural Plast. 2015:630932. doi: $10.1155 / 2015 / 630932$

Siebert, J. R., Eade, A. M., and Osterhout, D. J. (2015). Biomaterial approaches to enhancing neurorestoration after spinal cord injury: strategies for overcoming inherent biological obstacles. Biomed Res. Int. 2015:752572. doi: $10.1155 / 2015 / 752572$

Silva, N. A., Sousa, N., Reis, R. L., and Salgado, A. J. (2014). From basics to clinical: a comprehensive review on spinal cord injury. Prog. Neurobiol. 114, 25-57. doi: 10.1016/j.pneurobio.2013.11.002

Silver, J., Lorenz, S. E., Wahlsten, D., and Coughlin, J. (1982). Axonal guidance during development of the great cerebral commissures: descriptive and experimental studies, in vivo, on the role of preformed glial pathways. J. Comp. Neurol. 210, 10-29. doi: 10.1002/cne.902100103

Singh, A., Tetreault, L., Kalsi-Ryan, S., Nouri, A., and Fehlings, M. G. (2014). Global prevalence and incidence of traumatic spinal cord injury. Clin. Epidemiol. 6, 309-331. doi: 10.2147/CLEP.S68889

Smith, G. M., and Miller, R. H. (1991). Immature type-1 astrocytes suppress glial scar formation, are motile and interact with blood vessels. Brain Res. 543, 111-122. doi: 10.1016/0006-8993(91)91054-5

Smith, G. M., and Silver, J. (1988). Transplantation of immature and mature astrocytes and their effect on scar formation in the lesioned central nervous system. Prog. Brain Res. 78, 353-361. doi: 10.1016/S0079-6123(08)60 304-0

Smith-Thomas, L. C., Fok-Seang, J., Stevens, J., Du, J. S., Muir, E., Faissner, A., et al. (1994). An inhibitor of neurite outgrowth produced by astrocytes. J. Cell Sci. 107(Pt 6), 1687-1695.

Sofroniew, M. V. (2009). Molecular dissection of reactive astrogliosis and glial scar formation. Trends Neurosci. 32, 638-647. doi: 10.1016/j.tins.2009.08.002

Sofroniew, M. V., and Vinters, H. V. (2010). Astrocytes: biology and pathology. Acta Neuropathol. 119, 7-35. doi: 10.1007/s00401-009-0619-8

Suzuki, H., Kanchiku, T., Imajo, Y., Yoshida, Y., Nishida, N., Gondo, T., et al. (2015). Artificial collagen-filament scaffold promotes axon regeneration and long tract reconstruction in a rat model of spinal cord transection. Med. Mol. Morphol. 48, 214-224. doi: 10.1007/s00795-015-0104-5

Suzuki, Y., Kitaura, M., Wu, S. F., Kataoka, K., Suzuki, K., Endo, K., et al. (2002). Electrophysiological and horseradish peroxidase-tracing studies of nerve regeneration through alginate-filled gap in adult rat spinal cord. Neurosci. Lett. 318, 121-124. doi: 10.1016/S0304-3940(01)02359-X

Swanger, S. A., Neuhuber, B., Himes, B. T., Bakshi, A., and Fischer, I. (2005). Analysis of allogeneic and syngeneic bone marrow stromal cell graft survival in the spinal cord. Cell Transplant. 14, 775-786. doi: $10.3727 / 000000005783982594$

Sykova, E., Jendelova, P., Urdzikova, L., Lesny, P., and Hejcl, A. (2006). Bone marrow stem cells and polymer hydrogels-two strategies for spinal cord injury repair. Cell Mol. Neurobiol. 26, 1113-1129. doi: 10.1007/s10571-006-9007-2

Tabakow, P., Jarmundowicz, W., Czapiga, B., Fortuna, W., Miedzybrodzki, R., Czyz, M., et al. (2013). Transplantation of autologous olfactory ensheathing cells in complete human spinal cord injury. Cell Transplant. 22, 1591-1612. doi: 10.3727/096368912X663532

Tabesh, H., Amoabediny, G., Nik, N. S., Heydari, M., Yosefifard, M., Siadat, S. O. R., et al. (2009). The role of biodegradable engineered scaffolds seeded with Schwann cells for spinal cord regeneration. Neurochem. Int. 54, 73-83. doi: 10.1016/j.neuint.2008.11.002

Takahashi, Y., Tsuji, O., Kumagai, G., Hara, C. M., Okano, H. J., Miyawaki, A., et al. (2011). Comparative study of methods for administering neural stem/progenitor cells to treat spinal cord injury in mice. Cell Transplant. 20, 727-739. doi: $10.3727 / 096368910 X 536554$

Takami, T., Oudega, M., Bates, M. L., Wood, P. M., Kleitman, N., and Bunge, M. B. (2002). Schwann cell but not olfactory ensheathing glia transplants improve hindlimb locomotor performance in the moderately contused adult rat thoracic spinal cord. J. Neurosci. 22, 6670-6681.

Teng, Y. D., Lavik, E. B., Qu, X., Park, K. I., Ourednik, J., Zurakowski, D., et al. (2002). Functional recovery following traumatic spinal cord injury mediated by a unique polymer scaffold seeded with neural stem cells. Proc. Natl. Acad. Sci. U.S.A. 99, 3024-3029. doi: 10.1073/pnas.052678899

Tetzlaff, W., Okon, E. B., Karimi-Abdolrezaee, S., Hill, C. E., Sparling, J. S., Plemel, J. R., et al. (2011). A systematic review of cellular transplantation therapies for spinal cord injury. J. Neurotrauma 28, 1611-1682. doi: 10.1089/neu.2009.1177

Theele, D. P., Schrimsher, G. W., and Reier, P. J. (1996). Comparison of the growth and fate of fetal spinal iso- and allografts in the adult rat injured spinal cord. Exp. Neurol. 142, 128-143. doi: 10.1006/exnr.1996.0184

Theodore, N., Kim, K. D., Hsieh, P. C., Ray, W. Z., Barry, M., Layer, R., et al. (2016). 178 High abbreviated injury scale grade conversion rate following neurospinal scaffold implantation in acute thoracic complete abbreviated injury scale a spinal cord injury: potential mechanisms. Neurosurgery 63(Suppl. 1):171 doi: 10.1227/01.neu.0000489747.92587.18

Tian, W. M., Hou, S. P., Ma, J., Zhang, C. L., Xu, Q. Y., Lee, I. S., et al. (2005). Hyaluronic acid-poly-D-lysine-based three-dimensional hydrogel for traumatic brain injury. Tissue Eng. 11, 513-525. doi: 10.1089/ten.2005.11.513

Triolo, D., Dina, G., Lorenzetti, I., Malaguti, M., Morana, P., Del Carro, U., et al. (2006). Loss of glial fibrillary acidic protein (GFAP) impairs Schwann cell proliferation and delays nerve regeneration after damage. J. Cell Sci. 119, 3981-3993. doi: $10.1242 /$ jcs.03168

Vincent, A. J., Taylor, J. M., Choi-Lundberg, D. L., West, A. K., and Chuah, M. I. (2005). Genetic expression profile of olfactory ensheathing cells is distinct from that of Schwann cells and astrocytes. Glia 51, 132-147. doi: 10.1002/glia.20195

Vincent, A. J., West, A. K., and Chuah, M. I. (2003). Morphological plasticity of olfactory ensheathing cells is regulated by cAMP and endothelin-1. Glia 41, 393-403. doi: 10.1002/glia.10171

Vismara, I., Papa, S., Rossi, F., Forloni, G., and Veglianese, P. (2017). Current options for cell therapy in spinal cord injury. Trends Mol. Med. 23, 831-849. doi: 10.1016/j.molmed.2017.07.005

Volpato, F. Z., Fuhrmann, T., Migliaresi, C., Hutmacher, D. W., and Dalton, P. D. (2013). Using extracellular matrix for regenerative medicine in the spinal cord. Biomaterials 34, 4945-4955. doi: 10.1016/j.biomaterials.2013. 03.057

Vroemen, M., Aigner, L., Winkler, J., and Weidner, N. (2003). Adult neural progenitor cell grafts survive after acute spinal cord injury and integrate along axonal pathways. Eur. J. Neurosci. 18, 743-751. doi: 10.1046/j.1460-9568.2003.02804.x

Vroemen, M., Caioni, M., Bogdahn, U., and Weidner, N. (2007). Failure of Schwann cells as supporting cells for adult neural progenitor cell grafts in the acutely injured spinal cord. Cell Tissue Res. 327, 1-13. doi: 10.1007/s00441-006-0252-y

Wang, B., Zhao, Y., Lin, H., Chen, B., Zhang, J., Zhang, J., et al. (2006). Phenotypical analysis of adult rat olfactory ensheathing cells on 3-D collagen scaffolds. Neurosci. Lett. 401, 65-70. doi: 10.1016/j.neulet.2006.02.085

Wang, C., Sun, C., Hu, Z., Huo, X., Yang, Y., Liu, X., et al. (2017). Improved neural regeneration with olfactory ensheathing cell inoculated PLGA scaffolds in spinal cord injury adult rats. Neurosignals. 25, 1-14. doi: 10.1159/0004 71828

Wang, J. J., Chuah, M. I., Yew, D. T., Leung, P. C., and Tsang, D. S. (1995). Effects of astrocyte implantation into the hemisected adult rat spinal cord. Neuroscience 65, 973-981. doi: 10.1016/0306-4522(94)00519-B 
Wang, J. M., Zeng, Y. S., Wu, J. L., Li, Y., and Teng, Y. D. (2011). Cograft of neural stem cells and Schwann cells overexpressing TrkC and neurotrophin3 respectively after rat spinal cord transection. Biomaterials 32, 7454-7468. doi: 10.1016/j.biomaterials.2011.06.036

Weidner, N., Blesch, A., Grill, R. J., and Tuszynski, M. H. (1999). Nerve growth factor-hypersecreting Schwann cell grafts augment and guide spinal cord axonal growth and remyelinate central nervous system axons in a phenotypically appropriate manner that correlates with expression of L1. J. Comp. Neurol. 413, 495-506.

Williams, R. R., Henao, M., Pearse, D. D., and Bunge, M. B. (2015). Permissive Schwann cell graft/spinal cord interfaces for axon regeneration. Cell Transplant. 24, 115-131. doi: 10.3727/096368913X674657

Wu, L., Li, J., Chen, L., Zhang, H., Yuan, L., and Davies, S. J. (2013). Combined transplantation of GDAs(BMP) and hr-decorin in spinal cord contusion repair. Neural. Regen. Res. 8, 2236-2248. doi: 10.3969/j.issn.1673-5374.2013.24.003

Wu, M. C., Yuan, H., Li, K. J., and Qiu, D. L. (2015). Cellular transplantation-based evolving treatment options in spinal cord injury. Cell Biochem. Biophys. 71, 1-8. doi: 10.1007/s12013-014-0174-3

Xiao, Z., Tang, F., Tang, J., Yang, H., Zhao, Y., Chen, B., et al. (2016). One-year clinical study of NeuroRegen scaffold implantation following scar resection in complete chronic spinal cord injury patients. Sci. China Life Sci. 59, 647-655. doi: 10.1007/s11427-016-5080-z

Xu, X. M., Chen, A., Guenard, V., Kleitman, N., and Bunge, M. B. (1997). Bridging Schwann cell transplants promote axonal regeneration from both the rostral and caudal stumps of transected adult rat spinal cord. J. Neurocytol. 26, 1-16. doi: 10.1023/A:1018557923309

Xu, X. M., Guenard, V., Kleitman, N., Aebischer, P., and Bunge, M. B. (1995a). A combination of BDNF and NT-3 promotes supraspinal axonal regeneration into Schwann cell grafts in adult rat thoracic spinal cord. Exp. Neurol. 134, 261-272. doi: 10.1006/exnr.1995.1056

Xu, X. M., Guenard, V., Kleitman, N., and Bunge, M. B. (1995b). Axonal regeneration into Schwann cell-seeded guidance channels grafted into transected adult-rat spinal-cord. J. Comp. Neurol. 351, 145-160. doi: 10.1002/cne.903510113

Xu, X. M., Zhang, S. X., Li, H., Aebischer, P., and Bunge, M. B. (1999). Regrowth of axons into the distal spinal cord through a Schwann-cell-seeded minichannel implanted into hemisected adult rat spinal cord. Eur. J. Neurosci. 11, 1723-1740. doi: 10.1046/j.1460-9568.1999.00591.x
Zeng, X., Qiu, X. C., Ma, Y. H., Duan, J. J., Chen, Y. F., Gu, H. Y., et al. (2015). Integration of donor mesenchymal stem cell-derived neuron-like cells into host neural network after rat spinal cord transection. Biomaterials 53, 184-201. doi: 10.1016/j.biomaterials.2015. 02.073

Zhang, L. L., Zhang, H. T., Cai, Y. Q., Han, Y. J., Yao, F., Yuan, Z. H., et al. (2016). Anti-inflammatory effect of mesenchymal stromal cell transplantation and quercetin treatment in a rat model of experimental cerebral ischemia. Cell. Mol. Neurobiol. 36, 1023-1034. doi: 10.1007/s10571-0150291-6

Zhang, Y., and Barres, B. A. (2010). Astrocyte heterogeneity: an underappreciated topic in neurobiology. Curr. Opin. Neurobiol. 20, 588-594. doi: 10.1016/j.conb.2010.06.005

Zhao, R. R., Andrews, M. R., Wang, D., Warren, P., Gullo, M., Schnell, L., et al. (2013). Combination treatment with anti-Nogo-A and chondroitinase $\mathrm{ABC}$ is more effective than single treatments at enhancing functional recovery after spinal cord injury. Eur. J. Neurosci. 38, 2946-2961. doi: 10.1111/ ejn. 12276

Zhu, T. Q., Yu, D. H., Feng, J. X., Wu, X. J., Xiang, L., Gao, H. Y., et al. (2015). GDNF and NT-3 induce progenitor bone mesenchymal stem cell differentiation into neurons in fetal gut culture medium. Cell. Mol. Neurobiol. 35, 255-264. doi: 10.1007/s10571-014-0120-3

Zuidema, J. M., Desmond, G. P., Rivet, C. J., Kearns, K. R., Thompson, D. M. and Gilbert, R. J. (2015). Nebulized solvent ablation of aligned PLLA fibers for the study of neurite response to anisotropic-to-isotropic fiber/film transition (AFFT) boundaries in astrocyte-neuron co-cultures. Biomaterials 46, 82-94. doi: 10.1016/j.biomaterials.2014.12.046

Conflict of Interest Statement: The authors declare that the research was conducted in the absence of any commercial or financial relationships that could be construed as a potential conflict of interest.

Copyright (c) 2018 Liu, Schackel, Weidner and Puttagunta. This is an open-access article distributed under the terms of the Creative Commons Attribution License (CC $B Y)$. The use, distribution or reproduction in other forums is permitted, provided the original author(s) or licensor are credited and that the original publication in this journal is cited, in accordance with accepted academic practice. No use, distribution or reproduction is permitted which does not comply with these terms. 